\title{
Foraminiferal stratigraphy and palaeobathymetry of Paleocene-lowermost Oligocene deposits (Vezhany and Monastyrets nappes, Ukrainian Carpathians)
}

\author{
Svitlana HNYLKO ${ }^{1}$ and Oleh HNYLKO ${ }^{1, *}$
}

1 National Academy of Sciences of Ukraine, Institute of Geology and Geochemistry of Combustible Minerals, Naukova 3a, 79060 Lviv, Ukraine

Hnylko, S., Hnylko, O., 2016. Foraminiferal stratigraphy and palaeobathymetry of Paleocene-lowermost Oligocene deposits (Vezhany and Monastyrets nappes, Ukrainian Carpathians). Geological Quarterly, 60 (1): 77-105, doi: 10.7306/gq.1247

\begin{abstract}
Mainly pelagic/hemipelagic deposits of the Vezhany Nappe (Paleocene-lowermost Oligocene Metova Formation with a high content of planktonic foraminifera) and typical flysch deposits of the Monastyrets Nappe (Paleocene-Eocene Sushmanets Formation with common agglutinated foraminifera as well as the Eocene Drahovo Formation), of the southwestern inner part of the Ukrainian Carpathians have been studied. The Parvularugoglobigerina eugubina Zone (Lower Danian), Acarinina acarinata Zone (Upper Thanetian), Morozovella subbotinae Zone and Morozovella aragonensis Zone (Ypresian), Acarinina bullbrooki Zone and Acarinina rotundimarginata Zone (Lutetian), Subbotina corpulenta Zone and Subbotina vialovi Zone (Upper Priabonian-Lower Rupelian) based on planktonic foraminifera as well as the Rzehakina fissistomata sensu lato Zone (Paleocene), Glomospira charoides-Recurvoides smugarensis Zone (Ypresian), and an assemblage with Haplophragmoides parvulus (latest Middle Eocene-early Late Eocene) based on agglutinated foraminifera have been identified in these deposits. The deep-water agglutinated foraminifera of the "Rzehakina", "Rhabdammina" and "Paratrochamminoides" assemblages found in the typical flysch deposits of the Sushmanets Formation indicate lower slope to abyssal environments below the CCD. The generic composition and morphological features of planktonic and benthic foraminifera recovered from marls of the Metova Formation suggest pelagic/hemipelagic conditions at bathyal depths above the foraminiferal lysocline.
\end{abstract}

Key words: Ukrainian Carpathians, Paleocene-Eocene, foraminifera, biostratigraphy, palaeobathymetry.

\section{INTRODUCTION}

Paleocene-Eocene deposits make up a significant portion of the stratigraphic succession of the Ukrainian Carpathians and are different in facies from the underlying Cretaceous strata and the overlying Oligocene bituminous deposits (Vialov et al., 1981; Andreyeva-Grigorovich et al., 1985; Vialov et al., 1989). In some places, lowermost Oligocene strata are similar in facies to the Paleocene-Eocene deposits and they are also overlain by bituminous deposits (Andreyeva-Grigorovich, 1999). Investigations of the Paleocene-lowermost Oligocene deposits are important for understanding the geological structure and evolution of the Carpathian orogen. In the inner (southwestern) part of the Ukrainian Carpathians, the Paleocene-Eocene as well as the lowermost Oligocene deposits in some places belong to the sedimentary successions of the Vezhany and Monastyrets nappes (units). The stratigraphy of these deposits has been studied by Vialov (1954), Kulchytskyi et al. (1957), Kryvin

* Corresponding author, e-mail: ohnilko@yahoo.com

Received: March 25, 2015; accepted: August 8, 2015; first published online: September 9, 2015
(1960), Dabagyan et al. (1965, 1966), Smirnov (1973, 1988a, b, c with references therein), Gruzman and Dabagyan (1979), Golev (1982) and Oszczypko et al. (2005 with references therein). The calcareous deposits of the Vezhany Nappe contain abundant planktonic foraminifers and as such provide a unique opportunity to construct a biozonation of the Ukrainian Carpathians based on planktonic microfossils (AndreyevaGrigorovich et al., 1985; Hnylko and Hnylko, 2013). The palaeobathymetry of the Vezhany and Monastyrets Paleogene marine basins has not yet been a subject of thorough investigations; a few inferences have been made about the deep-water origin of the Lower Eocene variegated shales of the Monastyrets Unit (Hnylko and Hnylko, 2010) as well as about the bathymetry of the Paleocene-Eocene Vezhany Basin situated around the foraminiferal lysocline (Hnylko and Hnylko, 2013). Many new data (including micropalaeontological) have been obtained due to the mapping work and compilation of the Carpathian Series of Sheets of the State Geological Map of Ukraine at a scale of 1:200,000 (Matskiv, 2009; Matskiv et al., 2009). These data allowed us to considerably refine the geologic structure and stratigraphy of the inner (southwestern) part of the Ukrainian Carpathians and have become the basis of the present investigation. The aim of this paper is to describe the foraminiferal biostratigraphy and to interpret the some sedimentary environments of the Paleocene-lowermost Oligocene deposits of the Vezhany and Monastyrets units. 


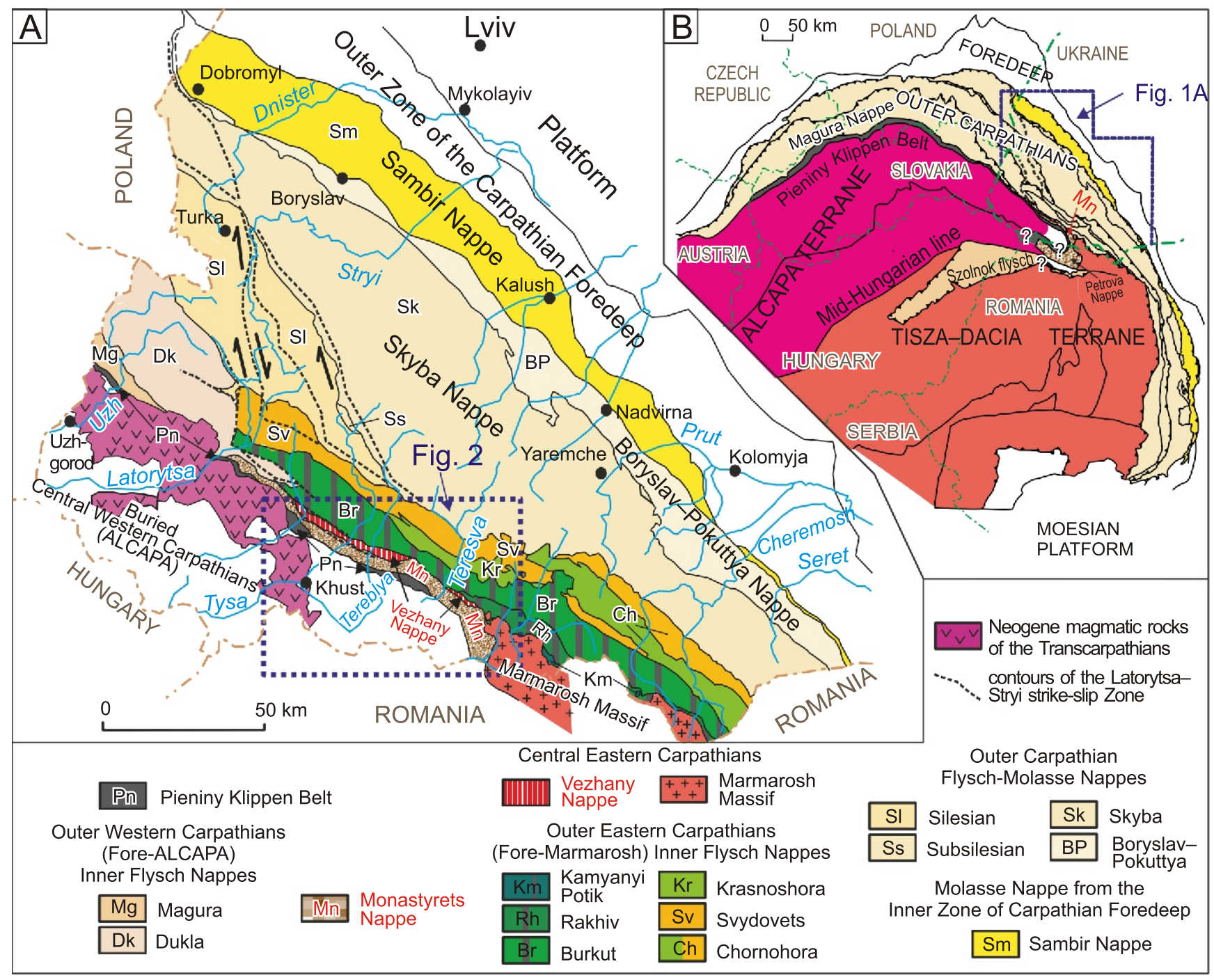

Fig. 1A - main tectonic units of the Ukrainian Carpathians (after Hnylko, 2011b, 2012); B - tectonic setting of the Ukrainian Carpathians, position of the terranes and main geological boundaries after Kovač et al. (1998), Csontos and Vörös (2004), Schmid et al. (2008); simplified, partly modified

\section{GEOLOGICAL SETTING}

The Vezhany Nappe (= Marmarosh Klippen Zone) and Monastyrets Nappe ( $\approx$ Drahovo Zone according to Byzova and Beer, 1974, and $\approx$ Marmarosh Flysch or Between Klippen Flysch) are placed in the inner part of the Ukrainian Carpathian orogen and are thrusted over the Outer Flysch Carpathians (Fig. 1). On the basis of previous research (Vialov et al., 1981; Kruglov, 1986; Csontos and Vörös, 2004; Schmid et al., 2008; Matskiv, 2009; Matskiv et al., 2009; Săndulescu, 2009; Hnylko, $2011 b, 2012)$, in this inner part of the orogen the following tectonic elements have been differentiated (Figs. 1 and 2): the Central Western Carpathians (part of the Alcapa Terrane buried under Neogene deposits of the Transcarpathian Depression) bounded by the Pieniny Klippen Belt and the Central Eastern Carpathians (the Marmarosh Crystalline Massif as well as Marmarosh Klippen Zone - parts of the Tisza-Dacia Terrane). The Monastyrets Nappe comprising typical flysch deposits is situated between the Alcapa and Tisza-Dacia terranes.

The Outer Carpathians consist of several stacked nappes and are considered as a Cretaceous-Neogene accretionary prism formed as a result of subduction of the basement of the
Carpathian sedimentary flysch basins beneath the Alcapa and Tisza-Dacia terranes - ancient microcontinents/continental fragments in the Alpine Tethys (Kovac et al., 1998; Csontos and Vörös, 2004; Oszczypko, 2006; Hnylko, 2012; Fig. 1). The remnant-type Carpathian flysch basins were situated between the Eurasian passive margin and the active edges of these terranes. The two nappe systems (accretionary palaeoprisms) converge in the Ukrainian Outer Carpathians: the Outer Western Carpathians and Outer Eastern Carpathians (Horvath and Galacz, 2006; Hnylko, 2012). The first system is located at the front of the Alcapa Terrane, and the second one is at the front of the Tisza-Dacia Terrane. The boundary area between the Outer Western and the Outer Eastern Carpathians is related to the Latorytsa-Stryi strike-slip Zone clearly distinguished in the Inner Flysch Nappes (Hnylko, 2011a, 2012; Fig. 1). The Monastyrets Nappe, located in the inner part of the Carpathians, can be regarded as a fragment of the accretionary prism built up in front of the Alkapa Terrane as a result of subduction of the basement of the flysch basin between the Alcapa and Tisza-Dacia terranes (Hnylko, 2012).

The Vezhany Nappe is located to the north-west of the Marmarosh Crystalline Massif. This nappe is thrust over the 


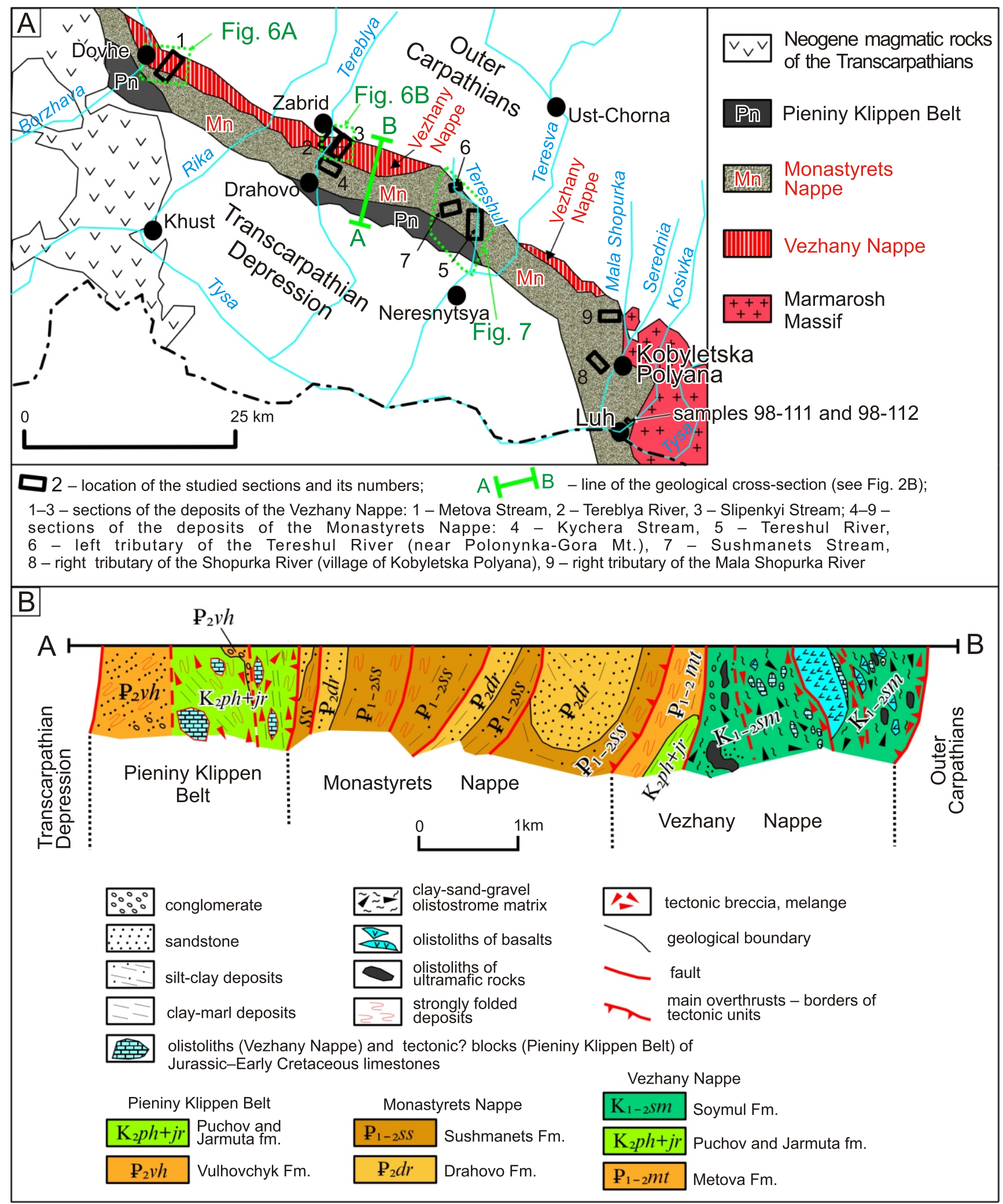

Fig. 2A - main tectonic units of the inner part of the Ukrainian Carpathians between Borzhava and Tysa River basins and position of the sections studied (for location see Fig. 1); B - geological cross-section of the inner part of the Ukrainian Carpathians along the Velyka Uholka River, Tereblya River basin (partly according Hnylko et al., 2015; for location see Fig. 2A) 


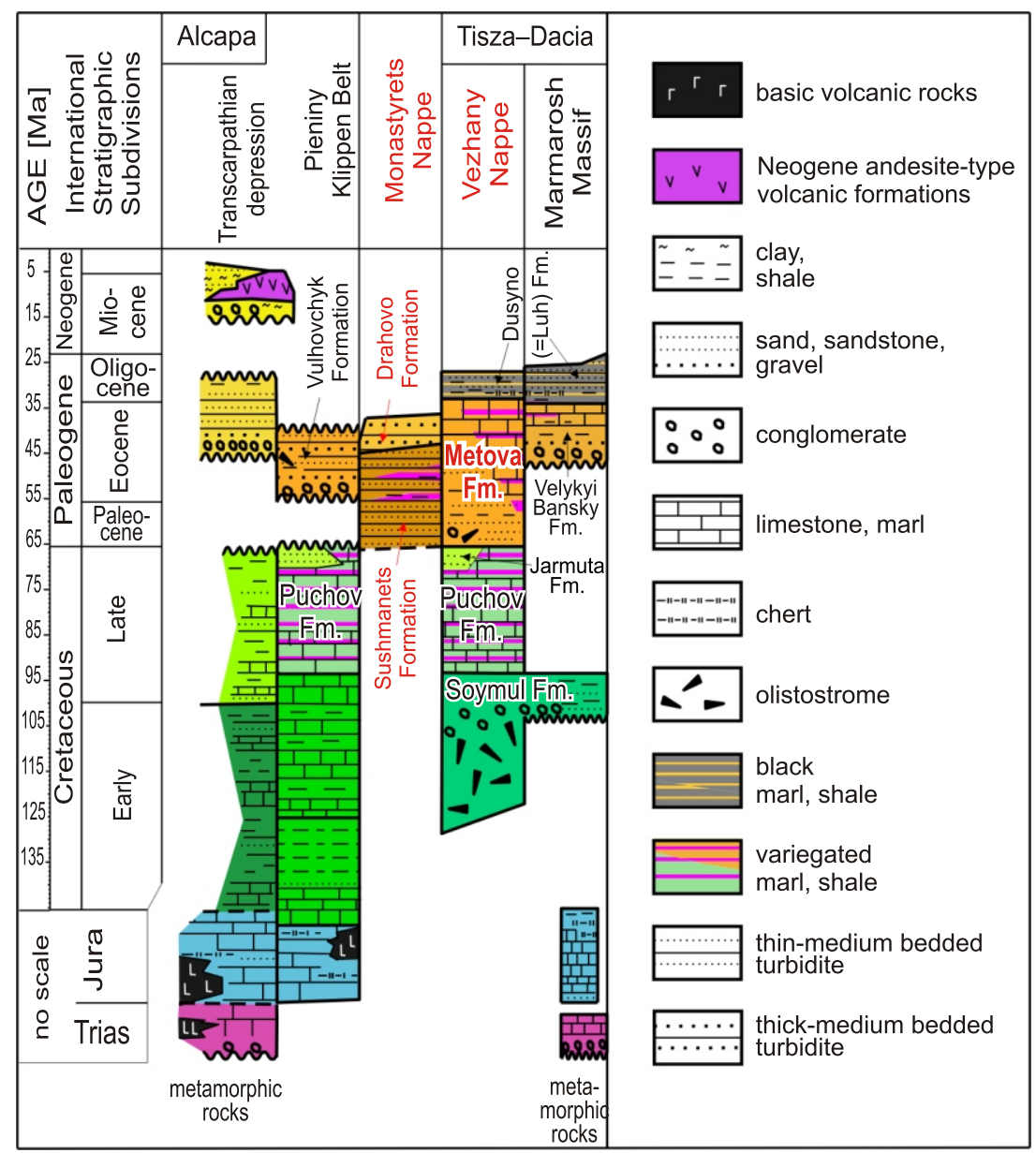

Fig. 3. Lithostratigraphy of the inner part of the Ukrainian Carpathians (after Andreeva-Grigorovich et al., 1985; Kruglov, 1986; Smirnov, 1988a, b, c; Vialov et al., 1989; Hnylko, 2011b)

Cretaceous flysch of the Outer Carpathians and is overthrust by the Monastyrets Nappe (see Figs. 1 and 2). The lower part of the Vezhany stratigraphic succession is represented by an Early Cretaceous $\sim 1000 \mathrm{~m}$ thick olistostrome (in places olistostrome-conglomerate) with olistoliths ("klippen") of the Proterozoic(?)-Paleozoic-Mesozoic rocks derived from the Marmarosh Massif as well as olistoliths of Mesozoic mafic-ultramafic rocks and of Early Cretaceous organogenic Urgonian-type limestones. This olistostrome sequence was placed within the lower part of the Soymul Formation (Kruglov, 1986). The olistostrome is covered by a depositional succession up to several hundred metres thick containing Albian-Cenomanian siltstones of the upper part of the Soymul Formation, Upper Cretaceous red marls of the Puchov Formation, Maastrichtian flysch of the Jarmuta Formation, and Paleogene deposits of the Metova and Dusyno formations (Andreyeva-Grigorovich et al., 1985; Vialov et al., 1989; Fig. 3). The Vezhany succession probably belongs to the tectonically uprooted sedimentary cover of the Marmarosh Massif and to the most northern parts of the Tisza-Dacia Terrane (Hnylko, $2011 \mathrm{~b}$ ). In addition, this succession is regarded as an equivalent of the Jasło Unit and the Northern Fore-Magura thrust sheet in the Polish Outer Carpathians (Oszczypko et al., 2005).

The Monastyrets Nappe is bounded by the Pieniny Klippen Belt along the south-west margin and thrust over the Oligocene and older deposits of both the Marmarosh Massif and Vezhany
Nappe or directly onto the Outer Carpathian Rakhiv or Burkut nappes in the north-east part (see Figs. 1-3). It consists of several small tectonic thrust sheets (Fig. 2). The Monastyrets stratigraphic succession is represented by flysch deposits up to $1700 \mathrm{~m}$ thick, assigned by some authors to the Eocene (Smirnov, 1973; Andreyeva-Grigorovich et al., 1985; Hnylko, 2008; Matskiv, 2009; Matskiv et al., 2009). Nevertheless, Cretaceous strata have been documented in the area of distribution of the flysch deposits of the Monastyrets Unit (Lomize and Maslakova, 1967; Vialov, 1988a, see below).

Most likely, the Monastyrets Nappe is the prolongation of the inner part of the Western Carpathian Magura Nappe (Byzova and Beer, 1974; Oszczypko et al., 2005) and the Eastern Carpathian Petrova and Leorgina nappes, as well as the Wild Flysch Nappe in Romania (Oszczypko et al., 2005 and references therein). The Magura-Monastyrets flysch units can be regarded as an equivalent of the Szolnok Unit (or part of this unit containing the Upper Cretaceous-Paleogene flysch deposits) in the pre-Neogene basement of the Pannonian Basin in Hungary (Zoltan Balla, pers. comm.; see also Nagymarosy and Baldi-Beke, 1993; Fig. 1). The Szolnok Unit can be traced westwards along the Mid-Hungarian Fault Zone towards Zagreb where it links up with the Sava Zone which represents the Paleogene suture between the Dinarides and the Tisza-Dacia Terrane (Schmid et al., 2008). 


\section{OUTLINE OF THE LITHOSTRATIGRAPHY AND PREVIOUS PALAEONTOLOGICAL INVESTIGATIONS OF THE PALEOCENE- LOWERMOST OLIGOCENE DEPOSITS}

Vezhany Nappe (Marmarosh Klippen Zone) Paleocene-lowermost Oligocene deposits are represented by the Metova Formation distinguished by Dabagyan et al. (1965). These deposits cover the Maastrichtian flysch assigned by Dabagyan et al. (1966) to the Jarmuta Formation, which conformably overlies the red marls of the Puchov Formation. The Jarmuta and Puchov formations have been distinguished in the Pieniny Klippen Belt; however, in Ukraine, these names are traditionally used for similar deposits of the Marmarosh Klippen Zone (Andreyeva-Grigorovich et al., 1985; Vialov et al., 1989 with references therein). The Metova Formation passes upwards into calcareous black marl with intercalations of sandstone, siderite and chert of the Oligocene Dusyno Fomation distinguished by Vialov (1954) (= Luh Formation after Kryvin, 1960, see Fig. 3).

At the bottom of the Metova Formation, debris-flow deposits (Oszczypko et al., 2005) are developed at the right bank of the Tereblya River near Zabrid (Fig. 4). These deposits lie in stratigraphically normal position on the Maastrichtian flysch (Andreyeva-Grigorovich et al., 2012), but previous researchers (Smirnov, 1973, 1988b and references therein) attributed them to a basal conglomerate lying on the Maastrichtian flysch with erosional unconformity. The Metova Formation is subdivided into two members. The lower member (of thickness $>100 \mathrm{~m}$ ) is composed of predominantly clastic deposits - thin- to medium-bedded grey siltstones, sandstones (Fig. 5A). Bouma divisions are indistinct in these deposits. Lenses of red and green marl were found in some sections of the lower member. The upper member of the Metova Formation (up to $80 \mathrm{~m}$ thick) is represented by pelagic/hemipelagic deposits that are bluish-grey or green and marly, with some red marls (Fig. 5B). The top part of the Metova Formation contains the Globigerina Marl (of a thickness up to a few metres) which is regionally distributed in the Carpathian region. In Ukraine, these (hemi)pelagic marls were named as the Sheshory Horizon (see Vialov, 1988b and references therein).

At the bottom of the Metova Formation, a nannoplankton assemblage belonging to Zone NP1 was found in a thin mudstone intercalation surrounded by debris-flow deposits (Andreyeva-Grigorovich et al., 2012; see Fig. 4) and in the upper part of this formation, an assemblage belonging to zones NP19, NP20 was recognized (Andreyeva-Grigorovich et al., 1987). The Oligocene nannoplankton was identified in a section of the Metova Formation along the Tereblya River (Oszczypko et al., 2005). The Early Eocene Nummulites planulatus Lamark, N. bolcensis Munier-Chalmas and the Middle Eocene Nummulites gallensis Heime and $N$. distans Deshayes have been found in the Metova Formation deposits (Golyev, 1982).

Biozones based on planktonic foraminifera and ranged from the Middle Paleocene to Late Eocene have been identified in the Metova Formation: Globorotalia angulata, GI. pseudomenardii, Gl. subbotinae, Gl. aragonensis, Acarinina bullbrooki, Hantkenina alabamensis, Globigerapsis index, Globigerina corpulenta (Gruzman and Dabagyan, 1979; Smirnov, 1988b). The Morozovella subbotinae, Morozovella aragonensis, Acarinina bullbrooki and Acarinina rotundimarginata zones have been identified in Paleocene-Eocene strata exposed along the Metova Stream (Hnylko and Hnylko, 2013).

Monastyrets Nappe. The Monastyrets sedimentary succession is represented by the Paleocene-Eocene deposits of both the Sushmanets Formation (Vialov, 1954) (= Shopurka Formation distinguished by Kryvin, 1960) and the Drahovo Formation (Kulchytskyi et al., 1957). The lower boundary of the Sushmanets Formation is at a tectonic surface and the age of the formation has remained controversial until now. The Drahovo Formation (Middle-Upper Eocene) conformably overlies the Sushmanets Formation and completes the sedimentary succession of the Monastyrets Nappe.

The Sushmanets Formation $>1000 \mathrm{~m}$ thick, is composed of thin- and locally medium-bedded flysch (Fig. 5C, D) which is characterised by Bouma divisions $T_{b c d e}, T_{a b c d e}, T_{c d e}$ and represents fine-grained turbidites, and in places "classic" medium-grained turbidites. Some strata are characterized by well-sorted grains, cross-bedded textures, and stronger bioturbation, most likely they represent deposits of bottom currents. The red and green mudstones generally have parallel and thinly layered textures suggesting their hemipelagic origin.

The Early Eocene Nummulites partshi Harpe was found in the deposits of the Sushmanets Formation (Golyev, 1982) and Early-Middle Eocene smaller foraminifers were identified in these deposits (Smirnov, 1973, 1988c; Hnylko, 2008). In the
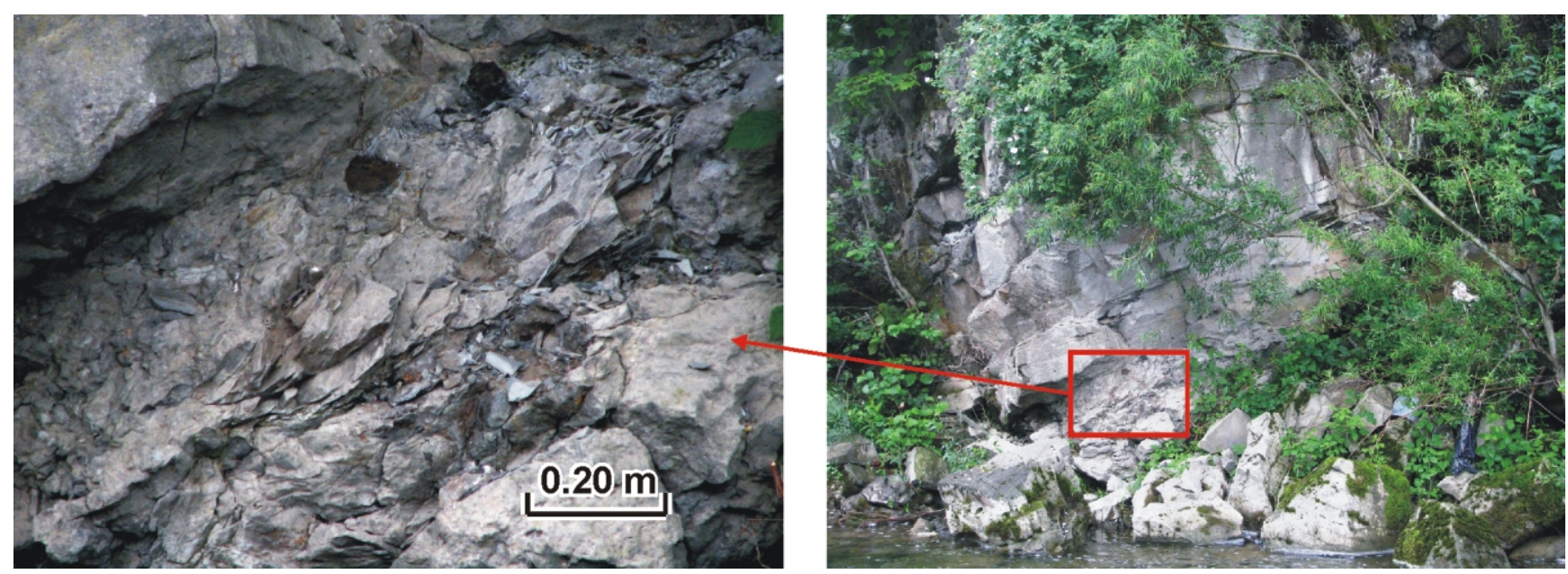

Fig. 4. The sandstones and debris-flow deposits at the bottom of the Metova Fm. in the right bank of the Tereblya River near Zabrid 

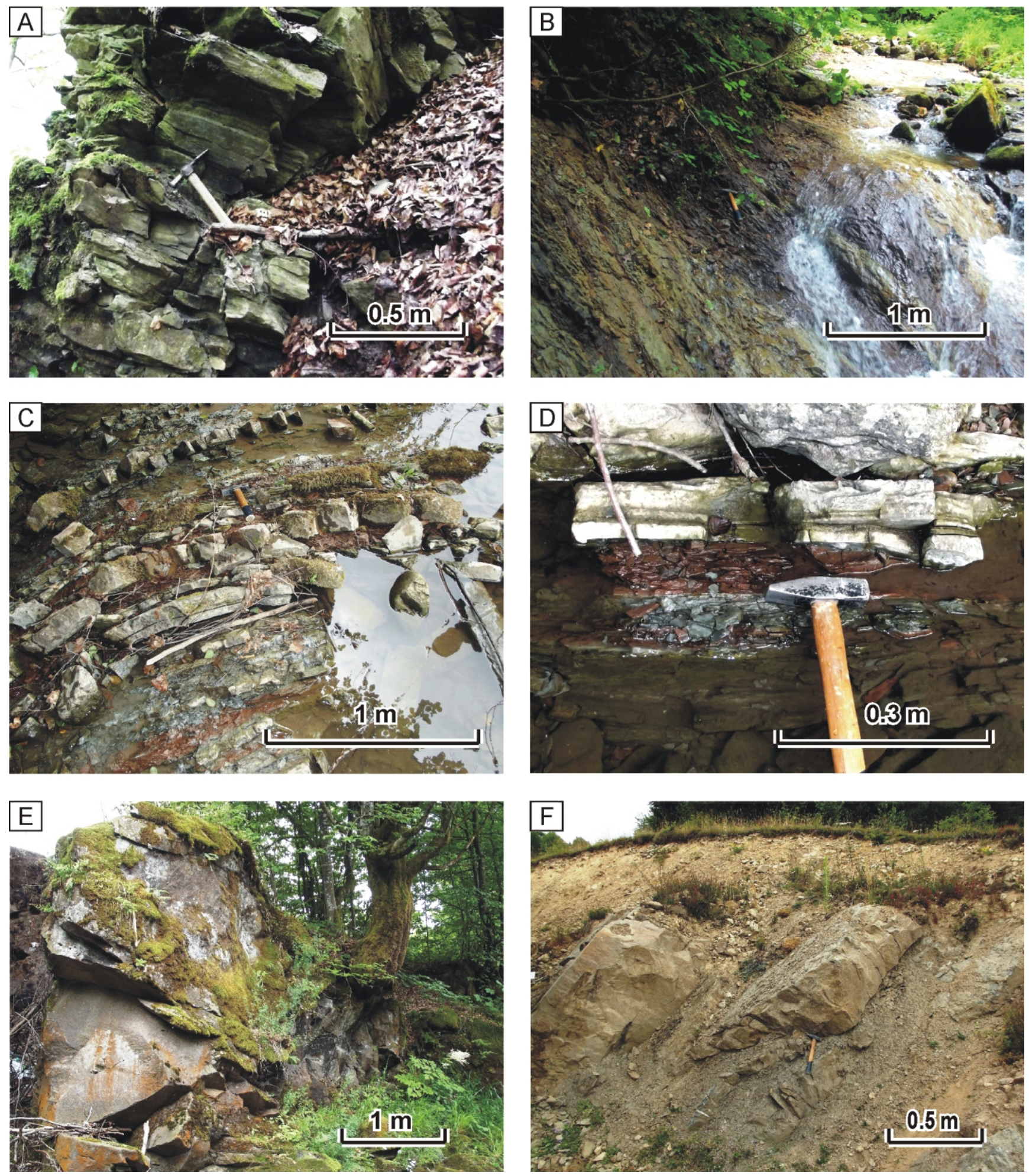

Fig. 5. Typical lithofacies units of the Vezhany (A, B) and Monastyrets (C-F) nappes

A - siltstones and sandstones of the lower member of the Metova Formation, Vezhany Stream - right inflow of the Mala Uholka River; B red-brown and green marls of the upper member of the Metova Formation, Kamenskyi Stream - right inflow of the Velyka Uholka River; C thin-bedded turbidites with variegated shales of the Sushmanets Formation, Velyka Uholka River near village of Velyka Uholka; D - green and red (variegated) shales and thin-bedded turbidite layer with $\mathrm{T}_{\mathrm{abc}}$ Bouma intervals, the Sushmanets Formation, Velyka Uholka River near village of Velyka Uholka; E - massive sandstones of the Drahovo Formation, Velyka Uholka River near village of Velyka Uholka; $\mathbf{F}$ thick-bedded sandstones of the Drahovo Formation, small erosional channel is visible in the bottom of the sandstone bed, Velyka Uholka River near village of Velyka Uholka 
area of distribution of the Monastyrets Unit, Late Cretaceous foraminifers have been identified in variegated mudstones (Lomize and Maslakova, 1967) and Inoceramus was found in flysch deposits near the village of Kalyna (see Vialov, 1988a). The deposits with Cretaceous fauna have an unclear (tectonic?) relationship with reliably dated deposits of the Monastyrets succession and need further investigation.

The Drahovo Formation, up to $700 \mathrm{~m}$ thick, is composed of massive sandstones (Fig. 5E, F), thick-bedded sandy deposits characterized locally by Bouma divisions $T_{a b c}, T_{a b}$. These deposits were apparently formed by high-density turbidity currents and grain- and debris- flows. Sporadically there are thin intercalations of siltstone and mudstone that may belong to the $T_{d e}, T_{e}$ Bouma intervals and/or represent hemipelagites. Middle-Late Eocene foraminifers have been found in this formation (Smirnov, 1988a; Hnylko, 2008).

\section{MATERIALS AND METHODS}

Micropalaeontological studies were carried out on 75 samples collected by O. Hnylko, S. Hnylko and B. Matskiv during 1998, 2003-2004 and 2009 from marly and clay deposits of probably pelagic/hemipelagic origin. Samples were collected from the outcrops along the nine studied sections of the Monastyrets and Vezhany units investigated during the geologi- cal mapping, and additional samples were taken near these sections (Tables 1-3 and Figs. 6-9). The weight of each sample processed was $200 \mathrm{~g}$. The rocks were disintegrated by a special hand-press, soaked in soda solution and washed in bags from capronic netting. The microfossils were selected from the dried, sand-silt fraction residues. Processing of samples was performed in the micropalaeontological laboratory of the Institute of Geology and Geochemistry of Combustible Minerals, NASU, Lviv. Foraminifera were identified by S. Hnylko. Determination of most species was carried out following to Kaminski and Geroch (1993), Olsson et al. (1999), Kaminski and Gradstein (2005) and Pearson et al. (2006). Photos of foraminifera were made using the scanning electron microscope JEOL-220 SEM in the Physical Research Laboratory of the Ivan Franko National University of Lviv.

The biostratigraphy has been based on planktonic and benthic foraminifers (Figs. 8 and 9). The foraminiferal zonations of the Ukrainian Carpathians (Maslakova, 1955; Mjatliuk, 1970; Ivanik and Maslun, 1977; Gruzman and Dabagyan, 1979; Andreyeva-Grigorovich et al., 1985; Hnylko and Hnylko, 2011, 2012,2013 ) in accordance with the zonations of Geroch and Nowak (1984), Olszewska (1997), Berggren et al. (1995) and Bugrova (2005) is applied here. Information about stratigraphic ranges of taxa is also derived from other work (Darakchieva, 1999; Olsson et al., 1999; Kaminski and Gradstein, 2005; Pearson et al., 2006; Waśkowska-Oliwa, 2005, 2008; Waśkowska, 2008, 2015; Golonka and Waśkowska, 2012).

Characterization of sections 1-3 of the Vezhany Unit

\begin{tabular}{|c|c|c|c|c|}
\hline $\begin{array}{l}\text { Section } \\
\text { number }\end{array}$ & Formation & $\begin{array}{l}\text { Thickness } \\
\text { of deposits }\end{array}$ & Section location & Description of deposits \\
\hline 1 & $\begin{array}{c}\text { Stratotype } \\
\text { section of } \\
\text { the Metova } \\
\text { Formation } \\
\text { (lower and } \\
\text { upper } \\
\text { members) } \\
\text { (Smirnov, } \\
\text { 1988b) }\end{array}$ & $\begin{array}{c}75 \mathrm{~m} \\
\text { (lower } \\
\text { member) } \\
60 \mathrm{~m} \text { (up- } \\
\text { per mem- } \\
\text { ber) }\end{array}$ & $\begin{array}{l}\text { Along the Metova } \\
\text { Stream (Borzhava } \\
\text { River basin) near } \\
\text { Dovhe in the } \\
\text { Transcarpathian Re- } \\
\text { gion (Figs. } 2,6 \text { and } \\
\text { 8). The beginning of } \\
\text { the section is placed } \\
300 \text { m downstream } \\
\text { from the mouth of the } \\
\text { first (counting from } \\
\text { below) right tributary } \\
\text { of the Metova } \\
\text { Stream. }\end{array}$ & $\begin{array}{l}\text { Thin- and medium-bedded grey sandstones, greenish-grey mudstones and } \\
\text { marls of the lower member are exposed at the beginning of the section } \\
\text { (sample 7036) and extend } 120 \text { m down (samples } 7036-1,7036-2 \text { and } \\
\text { 7036-3) along the Metova Stream. The Bouma divisions are not observed. } \\
\text { The lower boundary of the Metova Formation is not exposed. About } 50 \mathrm{~m} \\
\text { downstream, exposures of the green marls (sample 7036-4), and a further } \\
100-250 \text { m below, outcrops of red marls (sample 7036-5) are present. } \\
\text { These homogeneous and bedded marls are evidently hemipelagic/pelagic in } \\
\text { origin and are typical for the upper member. The highest part (including the } \\
\text { Globigerina Marl) and the upper limit of the formation are not exposed. } \\
\text { About } 100 \text { m downstream, we found debris of black mudstones and grey } \\
\text { sandstones of the Oligocene Dusyno Formation. }\end{array}$ \\
\hline 2 & $\begin{array}{l}\text { Metova } \\
\text { Formation } \\
\text { (lower } \\
\text { member) }\end{array}$ & $50 \mathrm{~m}$ & $\begin{array}{l}\text { Along the Tereblya } \\
\text { River near Zabrid and } \\
\text { Drahovo in the } \\
\text { Transcarpathian Re- } \\
\text { gion (Figs. } 2,6 \text { and } \\
\text { 8). The beginning of } \\
\text { the section is placed } \\
300 \mathrm{~m} \text { upstream from } \\
\text { the road bridge } \\
\text { across the Tereblya } \\
\text { River, which is lo- } \\
\text { cated near the former } \\
\text { mineral water factory } \\
\text { in the village of } \\
\text { Zabrid. }\end{array}$ & $\begin{array}{l}\text { Maastrichtian grey-green thin-bedded flysch is exposed in the riverbed at } \\
\text { the beginning of the section. This flysch is overlain by the debris-flow de- } \\
\text { posits }(0.6 \mathrm{~m} \text { thick) of the bottom of the Metova Formation (Fig. } 4 \text { ). These } \\
\text { chaotic deposits are composed of sharp-edged fragments of the Puchov } \\
\text { and Jarmuta formation "scattered" into a sandy matrix. There are intercala- } \\
\text { tions of clay sediments (sample } 29-2 \text { ) between the debris-flow layers. The } \\
\text { chaotic deposits are followed by thick-bedded coarse-grained sandstones } \\
\text { (10 m thick). The separate outcrops of the bedded gravelites, sandstones } \\
\text { and mudstones (samples } 29-3 ; 29-4 \text { and } 29-5) \text { of the lower member of the } \\
\text { Metova Formation are traced down } 200 \text { m along the Tereblya River. After } \\
\text { a further } 100 \text { m downstream, the tectonic thrust-sheet of the red marls of } \\
\text { the Upper Cretaceous Puchov Formation is exposed. }\end{array}$ \\
\hline 3 & $\begin{array}{c}\text { Metova } \\
\text { Formation } \\
\text { (lower and } \\
\text { upper } \\
\text { members) }\end{array}$ & $\begin{array}{c}100 \mathrm{~m} \\
\text { (lower } \\
\text { member) } \\
75 \text { m (up- } \\
\text { per mem- } \\
\text { ber) }\end{array}$ & $\begin{array}{l}\text { Along the Slipenkyi } \\
\text { Stream (left branch of } \\
\text { the Monastyr Stream, } \\
\text { which is the left tribu- } \\
\text { tary of the Tereblya } \\
\text { River) near Zabrid } \\
\text { and Drahovo in the } \\
\text { Transcarpathian Re- } \\
\text { gion (Figs. } 2,6 \text { and } \\
\text { 8). The beginning of } \\
\text { the section is placed } \\
\text { in } 800 \text { m upstream } \\
\text { from the mouth of the } \\
\text { Slipenkyi Stream. }\end{array}$ & $\begin{array}{l}\text { The tectonic contact of the red marls of the Puchov Formation and the } \\
\text { bedded blue-grey siltstones, sandstones of the lower member of Metova } \\
\text { Formation are exposed here. The lower member extends upstream about } \\
500 \mathrm{~m} \text { and is represented by folded thin- to medium-bedded polymictic } \\
\text { sandstones, in places gravelstones and conglomerates, siltstones, marls. } \\
\text { It is followed by the upper member developed as green-grey bedded marls } \\
\text { with thin intercalations of sandstones. The upper member is traced } 100 \mathrm{~m} \\
\text { upstream up to the confluence of the two upper tributaries of the Slipenyi } \\
\text { Stream. The exposures of the blue-grey and grey Globigerina Marl is } \\
\text { found in these tributaries near their confluence. The marls of the upper } \\
\text { member of the Metova Formation are covered by the Oligocene black } \\
\text { marls of the Dusyno Formation in outcrop } 30 \mathrm{~m} \text { upstream along the left up- } \\
\text { per tributaries. }\end{array}$ \\
\hline
\end{tabular}


Characterization of sections 4-7 of the Monastyrets Unit

\begin{tabular}{|c|c|c|c|c|}
\hline $\begin{array}{l}\text { Section } \\
\text { number }\end{array}$ & Formation & $\begin{array}{l}\text { Thickness } \\
\text { of deposits }\end{array}$ & Section location & Description of deposits \\
\hline 4 & $\begin{array}{l}\text { Sushmanets } \\
\text { Formation } \\
\text { (lower frag- } \\
\text { ment) }\end{array}$ & $600 \mathrm{~m}$ & $\begin{array}{l}\text { At the northwestern edge of } \\
\text { the village of Kychera near } \\
\text { Drahovo (Fig. 2). The begin- } \\
\text { ning of the section is placed } \\
\text { near the mouth of the } \\
\text { Kychera Stream (left tribu- } \\
\text { tary of the Tereblya River) } \\
1750 \text { m from the road bridge } \\
\text { across the Tereblya River } \\
\text { (the bridge situated near the } \\
\text { former mineral water factory } \\
\text { in Zabrid) downstream along } \\
\text { the Tereblya River. }\end{array}$ & $\begin{array}{l}\text { Thin- to medium-bedded flysch (up to } 100 \text { m thick), represented } \\
\text { by dark-grey mica sandstones, siltstones, dark-green } \\
\text { mudstones, is exposed in the lower part of the Kychera Stream. } \\
\text { Upstream as well as upward along the stratigraphic succession, } \\
\text { intercalations of red mudstones are found in the flysch. The up- } \\
\text { per part of the succession is represented by a horizon (up to } 30 \\
\text { m thick) of the red and green mudstones (samples } 59-53 \text { and } \\
59-52 \text { ) with thin intercalations of the fine-grained sandstones. } \\
\text { The age of the variegated horizon is assigned to the } \\
\text { Paleocene/Eocene boundary. The rocks are folded and cracked } \\
\text { in this section. }\end{array}$ \\
\hline 5 & $\begin{array}{l}\text { Sushmanets } \\
\text { and Drahovo } \\
\text { formations }\end{array}$ & $\begin{array}{l}800 \mathrm{~m} \\
\text { (Sushma- } \\
\text { nets Fm.) } \\
\text { and } 400 \mathrm{~m} \\
\text { (Drahovo } \\
\text { Fm.) }\end{array}$ & $\begin{array}{l}\text { Along both the Tereshul } \\
\text { River (right tributary of the } \\
\text { Teresva River) and its left } \\
\text { influent (Figs. } 2,7 \text { and } 9 \text { ). } \\
\text { The mouth of the influent is } \\
\text { located } 6400 \text { m from the } \\
\text { mouth of the Tereshul River } \\
\text { upstream along the river. } \\
\text { The beginning of the section } \\
\text { is placed at } 1400 \mathrm{~m} \text { from the } \\
\text { mouth of this left influent of } \\
\text { the Tereshul River upstream } \\
\text { along the influent. }\end{array}$ & $\begin{array}{l}\text { The grey sandstones (up to } 150 \text { m thick) of the lowermost part } \\
\text { of the stratigraphic succession are exposed at the beginning of } \\
\text { the section and traced } 300 \mathrm{~m} \text { downstream. The lower horizon of } \\
\text { the variegated (red and green) shales (the Paleocene-Eocene } \\
\text { boundary section, see Hnylko, 2008) are present } 150 \text { m down- } \\
\text { stream. Stratigraphically above, the thin- and medium-bedded } \\
\text { grey flysch ( } 200 \text { m thick) displaying the } T_{\text {bcde, }} \mathrm{T}_{\text {abcde, }} \mathrm{T}_{\text {cde }} \\
\text { Bouma's divisionsare exposed downstream along the influent. } \\
\text { The upper horizon (10-20 m thick) of the variegated shales (the } \\
\text { Lower/Middle Eocene boundary, see Hnylko, } 2008 \text { ) is fixed near } \\
\text { the mouth of the influent. The grey flysch with the Bouma divi- } \\
\text { sions } \mathrm{T}_{\text {bcde, }} \mathrm{T}_{\text {cde }} \text { (Sushmanets Formation) is traced down } 2300 \\
\text { m along the Tereshul River and gradually passes into sand- } \\
\text { stones (Drahovo Formation) extending a further } 2100 \mathrm{~m} \text { down- } \\
\text { stream along the river. }\end{array}$ \\
\hline 6 & $\begin{array}{c}\text { Sushmanets } \\
\text { Formation }\end{array}$ & $200 \mathrm{~m}$ & $\begin{array}{c}\text { The left tributary of the } \\
\text { Tereshul River near } \\
\text { Polonynka-Gora Mt. } \\
\text { (1047 m; Figs. 2, } 7 \text { and 9). }\end{array}$ & $\begin{array}{l}\text { The horizon of variegated shales (samples } 614 \text { and } 614-1) \text {, rep- } \\
\text { resented by alternation of green and red mudstone, is exposed } \\
\text { near the mouth of this left tributary. The thin- and medium-bed- } \\
\text { ded grey flysch (samples } 614-2 \text { and } 614-3 \text { ) is traced upstream } \\
250 \text { m along the tributary. }\end{array}$ \\
\hline 7 & $\begin{array}{l}\text { Stratotype } \\
\text { section of the } \\
\text { Sushmanets } \\
\text { Formation } \\
\text { (Matskiv, } \\
2007 \text { with } \\
\text { references } \\
\text { therein) }\end{array}$ & $1000 \mathrm{~m}$ & $\begin{array}{l}\text { Sushmanets Stream, the left } \\
\text { tributary of the Luzhanka } \\
\text { River in the Teresva River } \\
\text { Basin. The mouth of the trib- } \\
\text { utary is located } 9900 \text { m from } \\
\text { the mouth of the Luzhanka } \\
\text { River upstream along the } \\
\text { river (Figs. } 2,7 \text { and } 9 \text { ). }\end{array}$ & $\begin{array}{c}\text { Green-grey thin- and medium-bedded flysch, with the Bouma di- } \\
\text { visions } T_{\text {abcde }}, T_{\text {bcde, }}, T_{\text {cde }} \text {, is exposed along the Sushmanets } \\
\text { Stream (samples } 362,363 \text { and } 363-1 \text { ). Outcrops of thick-bed- } \\
\text { ded flysch and coarse-grained sandstones up to gravelstones } \\
\text { also are observed in some places. Sandy deposits of the } \\
\text { Drahovo Formation are present in the banks of the lower part of } \\
\text { the Sushmanets Stream (Fig. } 7 \text { ). }\end{array}$ \\
\hline
\end{tabular}

Characterization of sections 8 and 9 and additional samples of the Monastyrets Unit

\begin{tabular}{|c|c|c|c|}
\hline $\begin{array}{l}\text { Section } \\
\text { number }\end{array}$ & Formation & $\begin{array}{l}\text { Thickness } \\
\text { of deposits }\end{array}$ & Section location \\
\hline 8 & $\begin{array}{c}\text { Susmanets } \\
\text { Formtion }\end{array}$ & $900 \mathrm{~m}$ & $\begin{array}{l}\text { The right tributary of the Shopurka River } \\
\text { near the village of Kobyletska Polyana } \\
\text { (Figs. } 2 \text { and } 9 \text { ). The mouth of this tributary } \\
\text { is located } 1500 \mathrm{~m} \text { downstream along the } \\
\text { Shopurka River from the confluence of the } \\
\text { Mala Shopurka and Serednia rivers. The } \\
\text { beginning of the section is placed } 1000 \mathrm{~m} \\
\text { upstream from the mouth of this tributary. }\end{array}$ \\
\hline 9 & $\begin{array}{c}\text { Susmanets } \\
\text { Formtion }\end{array}$ & $500 \mathrm{~m}$ & $\begin{array}{l}\text { The right tributary of the Mala Shopurka } \\
\text { River on the northern edge of the village of } \\
\text { Kobyletska Polyana (Figs. } 2 \text { and } 9 \text { ). The } \\
\text { mouth of this tributary is located } 3750 \mathrm{~m} \text { up- } \\
\text { stream along the Mala Shopurka River from } \\
\text { the confluence of the Mala Shopurka and } \\
\text { Serednia rivers. The beginning of the sec- } \\
\text { tion is placed } 950 \mathrm{~m} \text { upstream along the } \\
\text { tributary from its mouth. }\end{array}$ \\
\hline
\end{tabular}

Additionaly samples

Description of deposits

The green thin-bedded flysch is present at the beginning of the section (sample 7028-5) and traced along the right tributary of the Shopurka River (samples 7028-4, 7028-3 and 7028-2). The green and red mudstones with sandstone intercalations of the upper variegated horizon are exposed

1600-1700 m upstream from the beginning (samples 7028-1 and 7028).

The lower variegated horizon are exposed (sample 7026-1). A further 200-300 m upstream,an outcrop of green thin- and medium-bedded flysch is found (samples 7026-2, 7026-3 and 7026-4) and $50 \mathrm{~m}$ above, the upper variegated horizon are exposed (sample 7026-5). Even further $400 \mathrm{~m}$ upstream after a covered interval, the upper variegated horizon are presented again, on the ridge between the Mala Shopurka and Apshytsa rivers (sample 7027 ).

Samples 98-111 (green mudstones) and 98-112 (red mudstones) were collected in the outcrop of the Sushmanets Formation located $3000 \mathrm{~m}$ upstream along the Kosivka River from its confluence into the Tysa River near village of Luh in the Transcarpathian Region (see Figs. 2 and 9). Samples 617 and 618 were collected in outsrops of the Sushmanets Formation near location of the sections 5 and 6 (see Fig. 7). Sample 29-50 was collected in outsrop of the Drahovo Formation near Drahovo. 


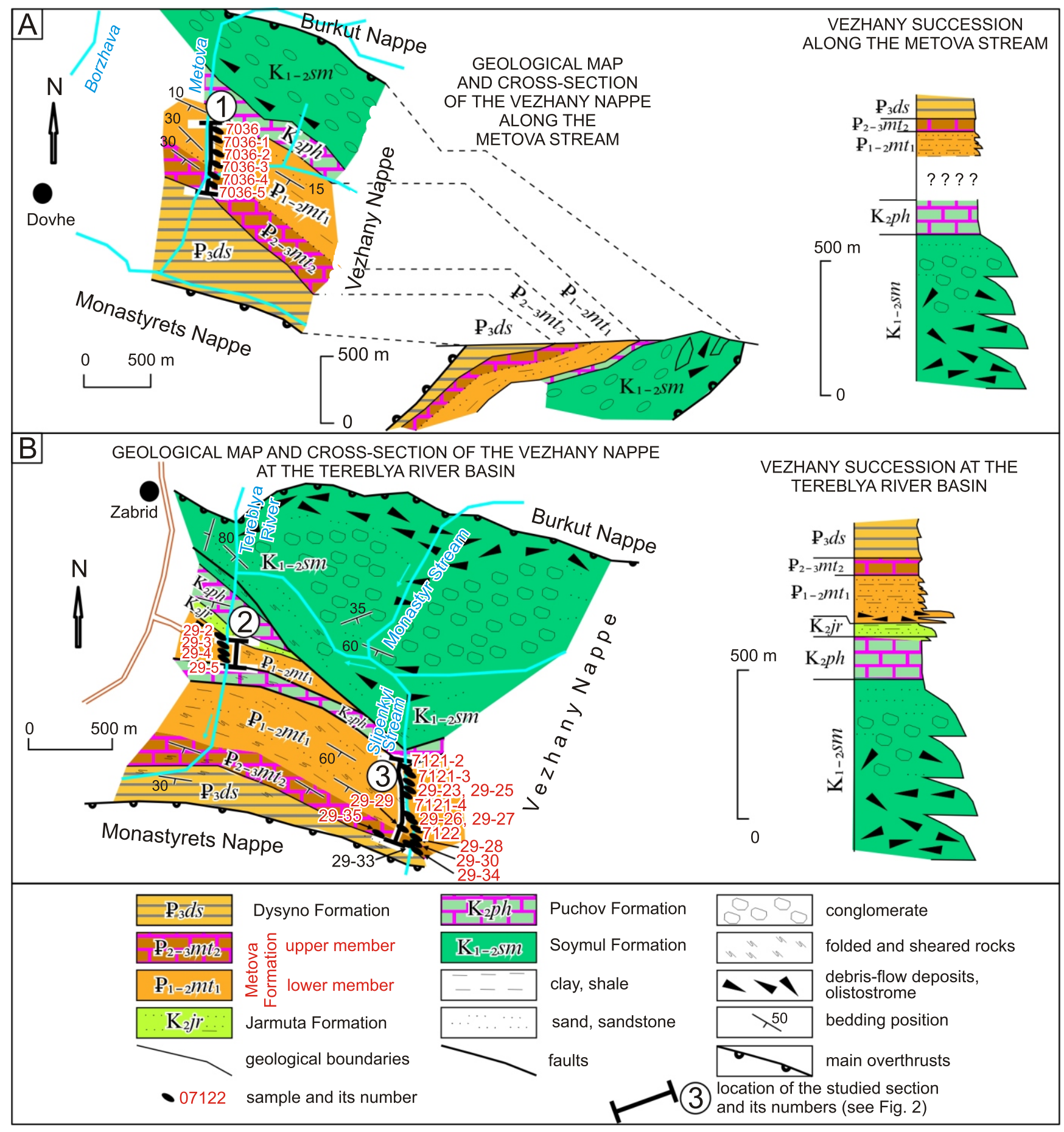

Fig. 6. Geological position of the sections studied of the Vezhany Unit: A - Metova Stream (section 1); B - Tereblya River basin (section 2, 3) 


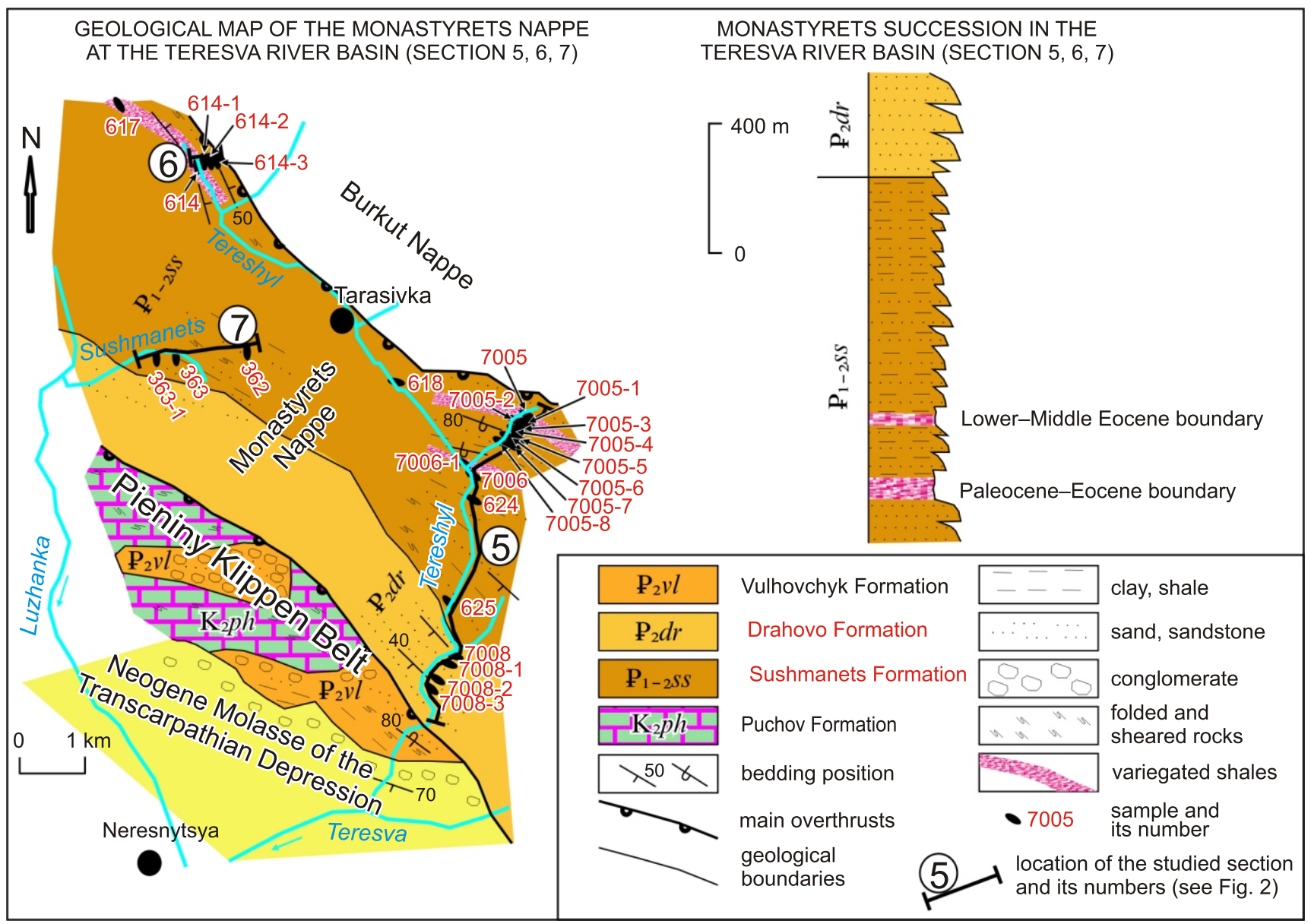

Fig. 7. Geological position of the studied sections 5, 6, 7 and samples 617, 618 from the Monasnastyrets Unit

For location see Figure 2

Palaeobathymetric interpretation was based on calculation of the percentage of planktonic and benthic specimens, analysis of generic and species composition, and morphological features of the foraminifera.

Both rich taphocenoses (approximately 40-200 tests per sample) and less rich taphocenoses (10-40 specimens per sample in several consecutive samples) were used to calculate of the percentage of planktonic and benthic foraminifera. The palaeobathymetric models of Murray (1976), Gradstein and Berggren (1981), Kaminski et al. (1988, 1989), Kuhnt and Kaminski (1989) and Gorbachik et al. (1996) were applied.

\section{RESULTS}

A total of 161 species of foraminifera were identified after processing of the samples: 92 species of agglutinated foraminifera belonging to 42 genera, 44 species of planktonic foraminifera belonging to 19 genera and 25 species of calcareous benthic foraminifera. The species identified are listed in Appendix $1^{*}$ and their distribution is shown in Figures 10-14. 86 characteristic species are illustrated in Figures 15-18. The preservation of the foraminifers studied is predominantly satisfactory. Calcareous foraminifers are recrystallised to varying degrees, while both the form and internal structures of the tests are preserved. Only a small number of specimens have poor preservation expressed by corrosion of the calcareous tests and by uncertainty of internal structure in some agglutinated foraminifers. Redeposited Late Cretaceous globotruncanids are generally numerous in the lowermost part of the Metova Formation and occur sporadically in the Eocene flysch deposits of the Sushmanets Formation among Paleogene foraminifera.

\section{INTERPRETATION}

\section{BIOSTRATIGRAPHY BASED ON PLANKTONIC FORAMINIFERA}

The foraminiferal zonation of the Ukrainian Carpathians (Maslakova, 1955; Mjatliuk, 1970; Gruzman and Dabagyan, 1979; Andreyeva-Grigorovich et al., 1985; Hnylko and Hnylko, 2013) in accordance with the zonations of Berggren et al. (1995) and Bugrova (2005) is applied here.

Parvularugoglobigerina eugubina Zone, Lower Danian Author: Luterbacher and Premoli Silva (1964)

Definition (according to Luterbacher and Premoli Silva, 1964; Berggren at al., 1995). - A biostratigraphic interval characterized by the total range of the nominate taxon Parvularugoglobigerina eugubina. 


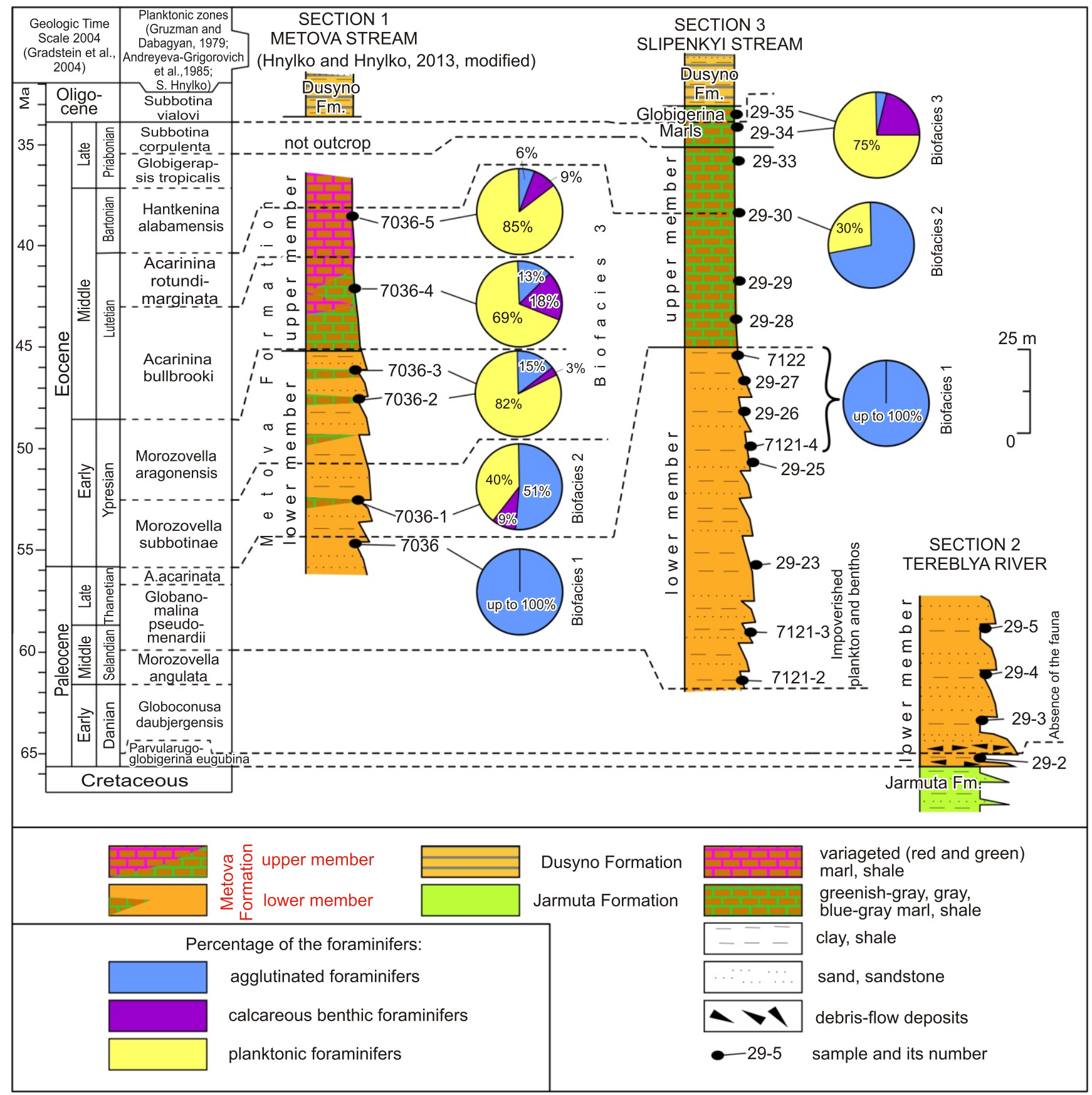

Fig. 8. Correlation of the sections studied and foraminiferal biofacies of the Paleocene-Lowermost Oligocene deposits of the Vezhany Nappe (Metova Formation)

For location see Figures 2 and 6 


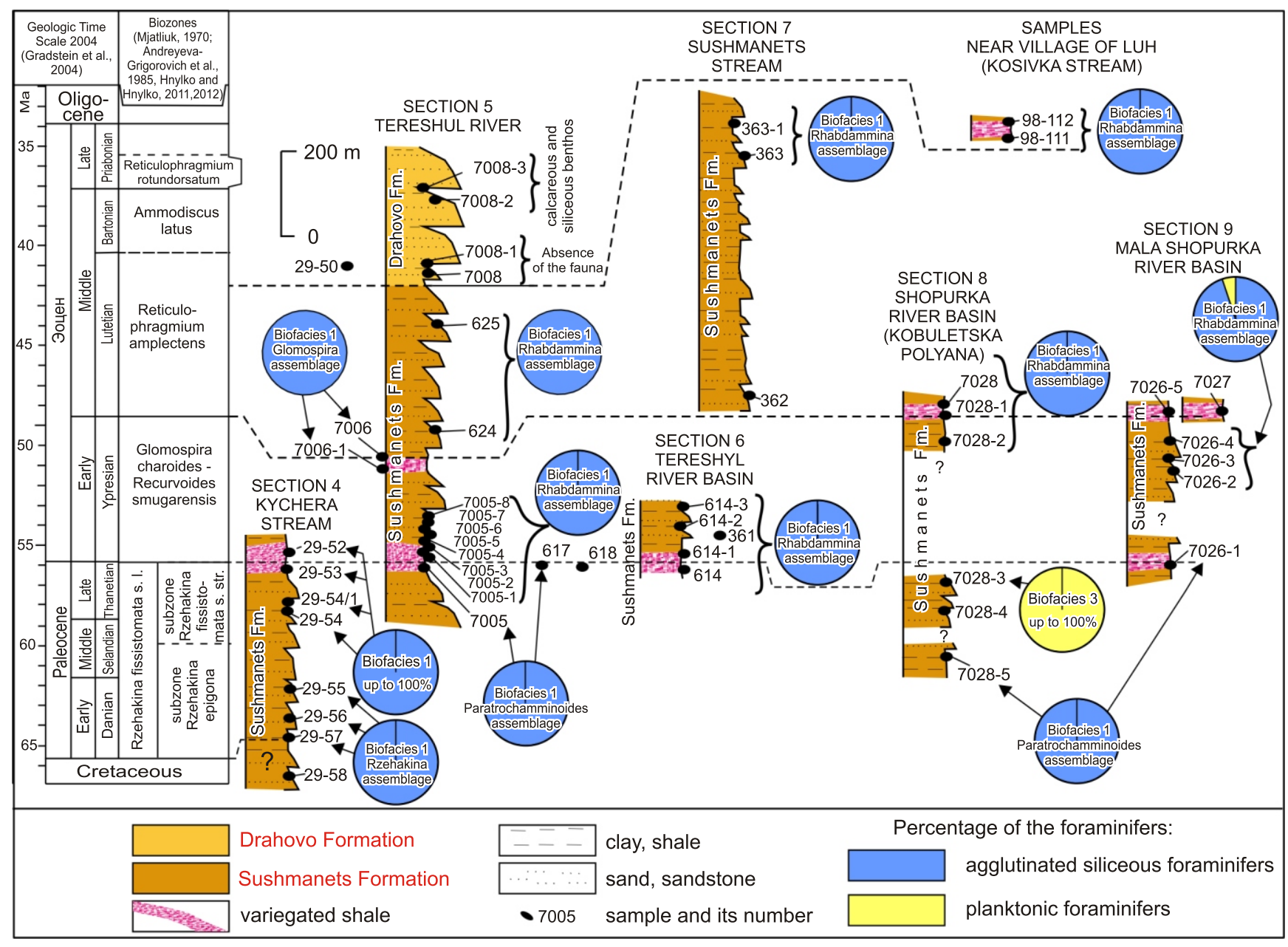

Fig. 9. Correlation of the sections studied and foraminiferal biofacies of the Paleocene-Eocene deposits of the Monastyrets Nappe

For location see Figures 2 and 7

$\mathrm{R}$ e $\mathrm{m}$ a $\mathrm{rks}$. - An assemblage belonging to this zone was identified in the lowermost part of the Metova Formation exposed in the right bank of the Tereblya River near the village of Zabrid (section 2, sample 29-2, see Figs. 6 and 8).

The zonal assemblage is represented by Parvularugoglobigerina eugubina (Fig. 17A-C) (size 0.11-0.15 mm), Eoglobigerina edita (Fig. 17D), E. senonica and numerous Praemurica aff. taurica (Fig. 17E) (size 0.15-0.20 mm). The Nannoplankton Zone NP1 (Lower Danian) was established in the same sample (Andreyeva-Grigorovich et al., 2012). Redeposited poorly preserved Cretaceous nannoplankton (Andreyeva-Grigorovich et al., 2012) and planktonic foraminifera of the genera Globotruncana and Globotruncanita are also present in this sample.

The Parvularugoglobigerina eugubina Zone corresponds to Zone $\mathrm{P} \alpha$ (Lower Danian) according to Berggren at al. (1995) and Wade at al. (2011).

The Globoconusa daubjergensis Zone (Danian) was distinguished in the Outer Ukrainian Carpathians by Andreyeva-Grigorovich et al. (1985), but deposits belonging to this zone were not found in the Vezhany and Monastyrets units.
The Morozovella angulata Zone and Globanomalina pseudomenardii Zone (Selandian-Thanetian) were not identified in the sections studied. These zones were recognized by Gruzman and Dabagyan (1979) in other sections of the Metova Formation.

Acarinina acarinata Zone, Upper Thanetian Author: Shutskaja (1962)

Definition. - Abundant nominate taxon Acarinina acarinata.

$\mathrm{R}$ e $\mathrm{m}$ a r k s. - This zone was identified in the Sushmanets Formation (section 8, sample 7028-3 see Figs. 2 and 9).

The zonal assemblage is represented by numerous specimens of Acarinina acarinata (Fig. 15X), Subbotina triloculinoides, Acarinina soldadoensis (Fig. 15P, Q) and rare Parasubbotina varianta and Acarinina triplex (Fig. 15Y). The poor foraminiferal assemblage (sample 618, see Figs. 7 and 9) 


\begin{tabular}{|c|c|c|c|c|c|c|}
\hline \multirow{4}{*}{ 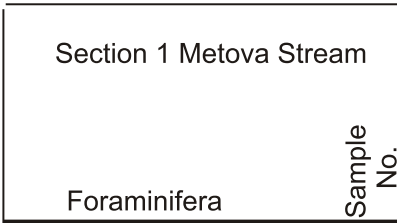 } & \multirow{2}{*}{\multicolumn{6}{|c|}{$\begin{array}{l}\text { Metova Formation upper } \\
\text { lower member } \mid \text { member }\end{array}$}} \\
\hline & & & & & & \\
\hline & \multirow{2}{*}{$\begin{array}{l} \\
\\
\\
\tilde{\rho} \\
\end{array}$} & \multicolumn{3}{|c|}{$\begin{array}{l}\text { Upresian } \\
\text { MS }\end{array}$} & $A B$ & $\mathrm{AR}$ \\
\hline & & 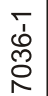 & 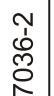 & $\begin{array}{l}m \\
0 \\
0 \\
\text { ర్ }\end{array}$ & $\begin{array}{l}\text { पे } \\
0 \\
\text { ర్ }\end{array}$ & ర్ల \\
\hline \multicolumn{7}{|l|}{ Silicobathysiphon subdivisus } \\
\hline Psammosiphonella cylindrica & & 0 & & () & 0 & \\
\hline Rhabdammina robusta & O & & & & & \\
\hline Psammosphaera pseudofusca & O & 0 & 0 & & O & \\
\hline \multicolumn{7}{|l|}{ Ammodiscus angustus } \\
\hline Glomospira charoides & 0 & O & 0 & 0 & 0 & \\
\hline \multicolumn{7}{|l|}{ Cyclammina placenta } \\
\hline Saccamminoides carpathicus & & & 0 & & & \\
\hline Textularia agg/utinans & 0 & () & & & & \\
\hline Trochamminna advena & 0 & 0 & & & & \\
\hline Karrerulina horrida & O & & & & & \\
\hline Nodosaria praesoluta & & & & 0 & & \\
\hline \multicolumn{7}{|l|}{ Anomalinoides acutus } \\
\hline \multicolumn{7}{|l|}{ Cibicidoides grossoconulus } \\
\hline Oridorsalis umbonatus & & O & & & O & \\
\hline \multicolumn{7}{|l|}{ Oridorsalis subumbonatus } \\
\hline \multicolumn{7}{|l|}{ Nuttallides truempyi } \\
\hline Nuttallides magnocamerata & & & & & O & \\
\hline \multicolumn{7}{|l|}{ Pleurostomella sp., Fig.18 P } \\
\hline \multicolumn{7}{|l|}{ Pleurostomella alazanensis cubensis } \\
\hline \multicolumn{7}{|l|}{ Nodosarella subnodosa } \\
\hline \multicolumn{7}{|l|}{ Stilostomella sp., Fig. $18 \mathrm{G}$} \\
\hline \multirow{2}{*}{\multicolumn{7}{|c|}{$\begin{array}{l}\text { Ellipsoglandulina labiata } \\
\text { Chilostomella chilostomelloides }\end{array}$}} \\
\hline & & & & & 0 & \\
\hline Chilostomella aff. balkanensis & & & & & 0 & \\
\hline \multicolumn{7}{|l|}{ Parasubbotina inaequispira } \\
\hline Subbotina eocaena & & () & & 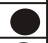 & O & \\
\hline \multicolumn{7}{|l|}{ Subbotina hagni } \\
\hline Subbotina yeguaensis & & 0 & () & (2) & () & () \\
\hline \multicolumn{7}{|l|}{ Globigerinatheka index } \\
\hline Globigerinatheka kugleri & & & & & & 0 \\
\hline Hantkenina liebusi & & & & & & () \\
\hline Acarinina acarinata & & O & & & & \\
\hline Acarinina bullbrooki & & & & & ( ) & 0 \\
\hline Acarinina pentacamerata & & 0 & & & & 0 \\
\hline Acarinina rotundimarginata & & & & & 0 & ( ) \\
\hline Acarinina triplex & & & & & () & O \\
\hline Morozovella aragonensis & & 0 & O & (2) & & \\
\hline Morozovella aff. formosa & & 0 & & & & \\
\hline Morozovella lensiformis & & & 0 & 0 & & \\
\hline Morozovella marginodentata & & 0 & & & & \\
\hline Planorotalites pseudoscitula & & & & & & \\
\hline Pseudohastigerina micra & & & & & & \\
\hline Pseudohastigerina wilcoxensis & & 0 & & & & \\
\hline Turborotalia cerroazulensis & & & & & & 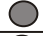 \\
\hline Turboro & & & & & & () \\
\hline Dipsidripella karpatica & & & & & $u$ & \\
\hline
\end{tabular}

The number of specimens in the sample: $-1-6 ; \quad 0-7-30$; - more than 30 ; juv. f. - juvenile form; $r$ - redeposited fauna (herein and for Figures 11-14)

\section{Fig. 10. Distribution of foraminifera in the Metova Formation}

Section 1 along the Metova Stream, Vezhany Nappe: MS Morozovella subbotinae Zone; MA - Morozovella aragonensis Zone; AB - Acarinina bullbrooki Zone; AR - Acarinina rotundimarginata Zone represented by poorly preserved Acarinina acarinata and Subbotina triloculinoides likely corresponds to this zone too.

The Acarinina acarinata Zone corresponds to the zone of the same name in Crimea and the North Caucasus (Bugrova, 2005).

\author{
Morozovella subbotinae Zone, Lower Ypresian \\ Author: Morozova (1946)
}

D e f i n i t i o n. - The biostratigraphic interval between the occurrence of numerous specimens of the nominate taxon Morozovella subbotinae and the last occurrence (LO) of Morozovella marginodentata.

$\mathrm{R}$ e $\mathrm{m}$ a r k s. - The upper part of this zone was identified in the Metova Formation (section 1, sample 7036-1, see Figs. 6 and 8).

The zonal assemblage includes Morozovella marginodentata (Fig. 17O), M. aff. formosa (Fig. 17P), Subbotina eocaena, S. yeguaensis, Acarinina pentacamerata and Pseudohastigerina wilcoxensis. The first occurrence (FO) of Morozovella aragonensis is observed.

This zonal assemblage corresponds to the top of the P6 Zone in the zonation of Berggren et al. (1995) and to the upper part of the Morozovella subbotinae Zone of Crimea and the North Caucasus (Bugrova, 2005).

\section{Morozovella aragonensis Zone, Upper Ypresian} Author: Khalilov (1948)

D e f i n i t i o n. - The biostratigraphic interval between the FO of the nominate taxon Morozovella aragonensis and the occurrence of numerous Acarinina bullbrooki.

$\mathrm{R}$ e $\mathrm{m}$ a r k s. - This zone was identified in intercalations of green marl in the upper part of the lower member of the Metova Formation (section 1, samples 7036-2 and 7036-3, see Figs. 6 and 8).

The zonal assemblage is composed of numerous Morozovella aragonensis (Fig. 17T-V), Morozovella lensiformis (Fig. 17X) and Parasubbotina inaequispira (Fig. 17W) as well as by abundant Subbotina eocaena and $S$. yeguaensis. The FO of Subbotina hagni is observed in the upper part of this zone.

The Morozovella aragonensis Zone corresponds to zones of the same name in Crimea and the North Caucasus (Bugrova, 2005), the Slovakian Carpathians (Fusán, 1983) and the P7-P9 zones of Berggren et al. (1995).

Acarinina bullbrooki Zone, Lower Lutetian Author: Bolli (1957)

Definition. - Abundant nominate taxon Acarinina bullbrooki.

$\mathrm{R}$ e $\mathrm{m}$ a r k s. - This zone was identified in green marls in the lower part of the upper member of the Metova Formation (section 1, sample 7036-4, see Figs. 6 and 8).

The zonal assemblage is composed of numerous Acarinina bullbrooki (Fig. 17Y), A. triplex, Subbotina yeguaensis, S. eocaena (Fig. 17Z) and S. hagni as well as of rare Dipsidripella 


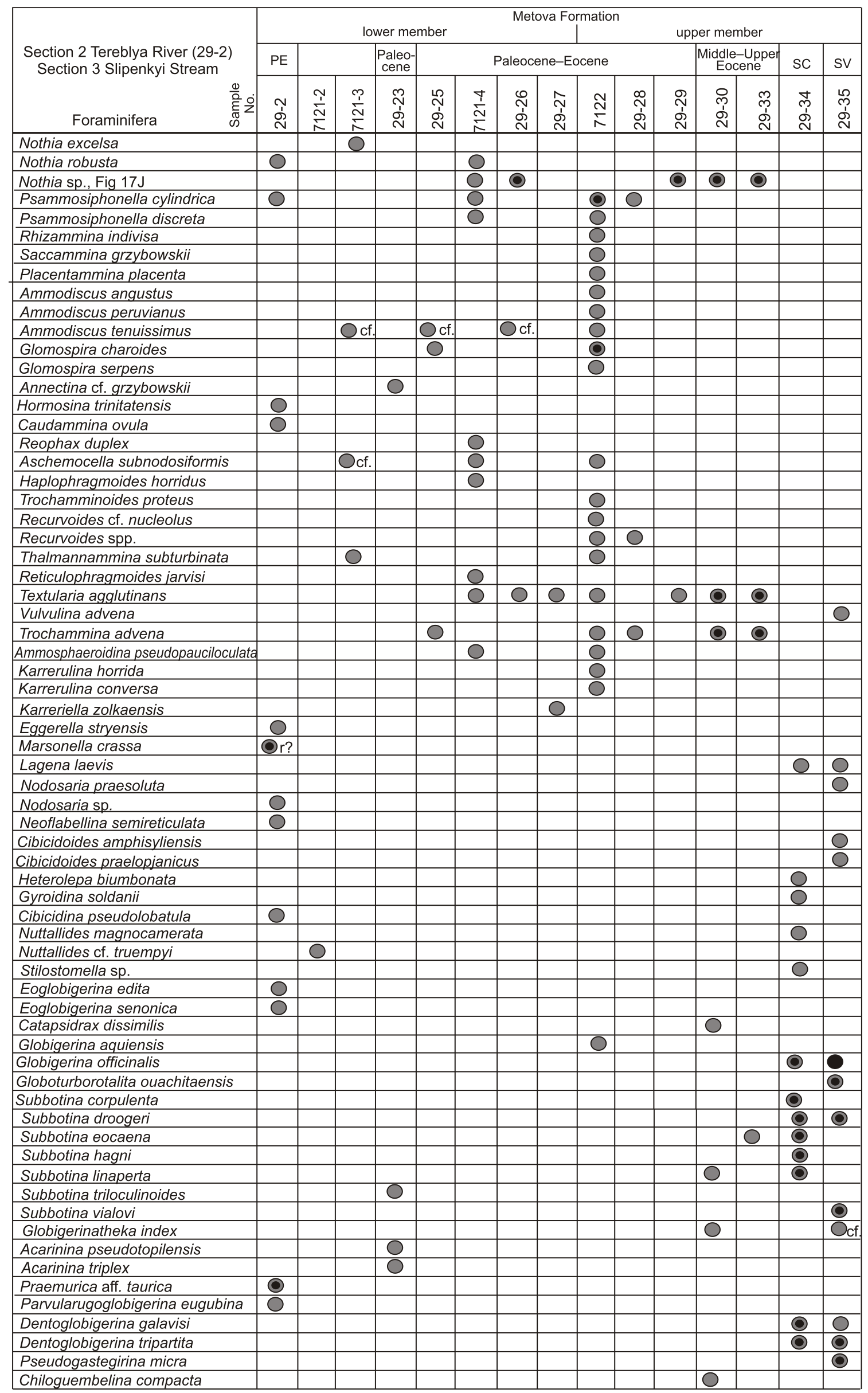

Fig. 11. Distribution of foraminifera in the Metova Formation

Section 2 along the Tereblya River and section 3 along the Slipenkyi Stream, Vezhany Nappe: PE Parvularugoglobigerina eugubina Zone; SC - Subbotina corpulenta Zone; SV - Subbotina vialovi Zone 


\begin{tabular}{|c|c|c|c|c|c|c|c|c|}
\hline \multirow{3}{*}{$\begin{array}{c}\text { Section } 4 \text { Kychera Stream } \\
\text { Foraminifera }\end{array}$} & \multicolumn{8}{|c|}{ Sushmanets Formation } \\
\hline & \multicolumn{3}{|c|}{$\begin{array}{l}\text { Cretaceous- } \\
\text { Paleocene }\end{array}$} & \multicolumn{3}{|c|}{$\begin{array}{l}\text { Paleocene } \\
\text { RzF }\end{array}$} & \multirow{2}{*}{ 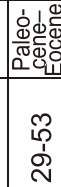 } & \multirow{2}{*}{ 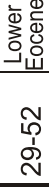 } \\
\hline & $\begin{array}{l}\infty \\
\infty \\
1 \\
\text { ని }\end{array}$ & $\begin{array}{l}\hat{L} \\
\stackrel{2}{N} \\
\text { D }\end{array}$ & $\begin{array}{l}0 \\
\text { L } \\
\text { N̦ } \\
\text { N }\end{array}$ & $\begin{array}{l}\text { م⿱ } \\
\text { N̦ } \\
\text { N }\end{array}$ & $\begin{array}{l}\text { 守 } \\
\text { N̦ } \\
\text { N }\end{array}$ & $\begin{array}{l}\text { ț } \\
\text { S } \\
\text { న }\end{array}$ & & \\
\hline Nothia robusta & & () & & & & & & \\
\hline Rhizammina indivisa & 0 & & & & & & & \\
\hline Silicobathysiphon gerochi & () & & & & & & & \\
\hline Silicobathysiphon spp. & & & & () & & O & & \\
\hline Psammosiphonella cylindrica & & 0 & & & & & & \\
\hline Placentammina placenta & & & & & & O & & \\
\hline Ammodiscus angustus & & & 0 & 0 & & & & \\
\hline Ammodiscus tenuissimus & & & & & & O & & O \\
\hline Glomospira charoides & & & & & & & O & O \\
\hline Glomospira serpens & & & 0 & & & & & \\
\hline Glomospira diffundens & & O & & & & & & \\
\hline Annectina grzybowskii & & 0 & & & & & & \\
\hline Rzehakina epigona & & 0 & & & & & & \\
\hline Rzehakina fissistomata & & & & 0 & & & & \\
\hline Subreophax scalaris & & & & 0 & & & & \\
\hline Subreophax splendidus & & 0 & & & O & & & \\
\hline Hormosina velascoensis & & O & 0 & 0 & & & & \\
\hline Caudamminna ovula & & & & 0 & & & & \\
\hline Kalamopsis grzybowskii & O & & & & & & & \\
\hline Aschemocella grandis & 0 & & & & & & & \\
\hline Aschemocella subnodosiformis & & & & & 0 & & & \\
\hline Haplophragmoides walteri & & & & & 0 & & & 0 \\
\hline Lituotuba lituiformis & & 0 & & & & & & \\
\hline Conglophragmium irregularis & & 0 & & & & 0 & & 0 \\
\hline Paratrochamminoides gorayskii & & & 0 & & & & & \\
\hline Paratrochamminoides olszewski & & O & & & & & & \\
\hline Trochamminoides proteus & & & 0 & & & & & \\
\hline Trochamminoides subcoronatus & & O & & & & & & \\
\hline Popovia beckmanni & & & & 0 & 0 & 0 & 0 & \\
\hline Saccamminoides carpathicus & & & & & & & & 0 \\
\hline Recurvoides varius & & & & & 0 & () & & \\
\hline Spiroplectammina spectabilis & & O & & & & & & \\
\hline Spiroplectammina subhaeringensis & & & & 0 & & & & \\
\hline Trochammina globigeriniformis & & & 0 & & 0 & 0 & 0 & O \\
\hline Ammosphaeroidina pseudopauciloculata & & & & & & & & 0 \\
\hline Karrerulina horrida & & & & & & & 0 & \\
\hline Cibicidoides padellus & O & & & Ocf & & & & \\
\hline Chilostomella spp. & 0 & & & & & & & \\
\hline Rugoglobigerina cf. macrocephala & O & & & & & & & \\
\hline Subbotina aff. triloculinoides & & & & & & & 0 & \\
\hline Morozovella angulata & & & & & O & & & \\
\hline
\end{tabular}

Fig. 12. Distribution of foraminifera in the Sushmanets Formation

Section 4 along the Kychera Stream, Monastyrets Nappe: RzF Rzehakina fissistomata Zone

karpatica (Fig. 17A1), Acarinina rotundimarginata and Pseudohastigerina micra (Fig. 17B1).

The Acarinina bullbrooki Zone corresponds to the zone of the same name in Crimea and the North Caucasus (Bugrova, 2005), and the Turborotalia crassata densa Zone of the Slovakian Carpathians (Fusán, 1983).

Acarinina rotundimarginata Zone, Upper Lutetian Author: Subbotina (1953)

D e f i n i t i o n. - The abundant nominate taxon Acarinina rotundimarginata outnumbers Acarinina bullbrooki.
$\mathrm{R}$ e $\mathrm{m}$ a r k s. - This zone was identified in red marls of the upper member of the Metova Formation (section 1, sample 7036-5, see Figs. 6 and 8).

The zonal assemblage includes Acarinina rotundimarginata (Fig. 18A), A. bullbrooki, A. triplex, A. pentacamerata, Subbotina yeguaensis, S. eocaena, S. hagni (Fig. 18E), Hantkenina liebusi (Fig. 18I, J), Globigerinatheka kugleri, G. index (Fig. 18H), Turborotalia frontosa (Fig. 18D), T. cerroazulensis (Fig. 18B), as well as abundant small Pseudohastigerina micra (Fig. 18C) and Dipsidripella karpatica.

The Acarinina rotundimarginata Zone corresponds to the zone of the same name in Crimea and the North Caucasus (Bugrova, 2005) and the P12 Zone of Berggren et al. (1995).

The Hantkenina alabamensis Zone (Bartonian) was not identified in the sections studied. This zone was recognised by Gruzman and Dabagyan (1979) in other sections of the Metova Formation.

A poor planktonic foraminiferal association represented by Globigerinatheka index (Fig. 18L), Catapsydrax dissimilis (Fig. 18M), Subbotina linaperta, and Chiloguembelina compacta (Fig. 18N) was identified in grey calcareous mudstone of the upper member of the Metova Formation (section 3, sample 29-30, see Figs. 6 and 8 ). The age of this association can be interpreted as Upper Lutetian-Priabonian.

\section{Subbotina corpulenta Zone, Upper Priabonian- lowermost part of Lower Rupelian Author: Subbotina (1960)}

D e finition. - The biostratigraphic interval between the occurrence of numerous specimens of the nominate taxon Subbotina corpulenta and the LO of Subbotina corpulenta.

R e marks. - This zone was identified in the Globigerina Marl of the upper member of the Metova Formation (section 3, sample 29-34, see Figs. 6 and 8). An assemblage composed of abundant planktonic foraminifers, both large $(0.5-0.9 \mathrm{~mm})$ and small $(0.15-0.25 \mathrm{~mm})$ was found here. The large forms are represented by Subbotina corpulenta (Fig. 18Q), Subbotina hagni, S. linaperta, S. eocaena, Dentoglobigerina galavisi (Fig. 18R), and the small ones consist of Globigerina officinalis and Subbotina droogeri.

The assemblage determined in sample 29-34 from the Metova Formation corresponds to the upper part of the Globigerina corpulenta Zone sensu Dabagyan (see Andreyeva-Grigorovich et al., 1987).

The Globigerina corpulenta Zone, identified in the Ukrainian Carpathians, corresponds to Zone NP21 and, in some successions, to the lower part of Zone NP22 (Andreyeva-Grigorovich et al., 1985,1987).

Subbotina vialovi Zone, Lower Rupelian Author: Vialov et al. (1963)

D e f i n i t i o n. - A biostratigraphic interval characterized by the total range of the nominate taxon Subbotina vialovi. 


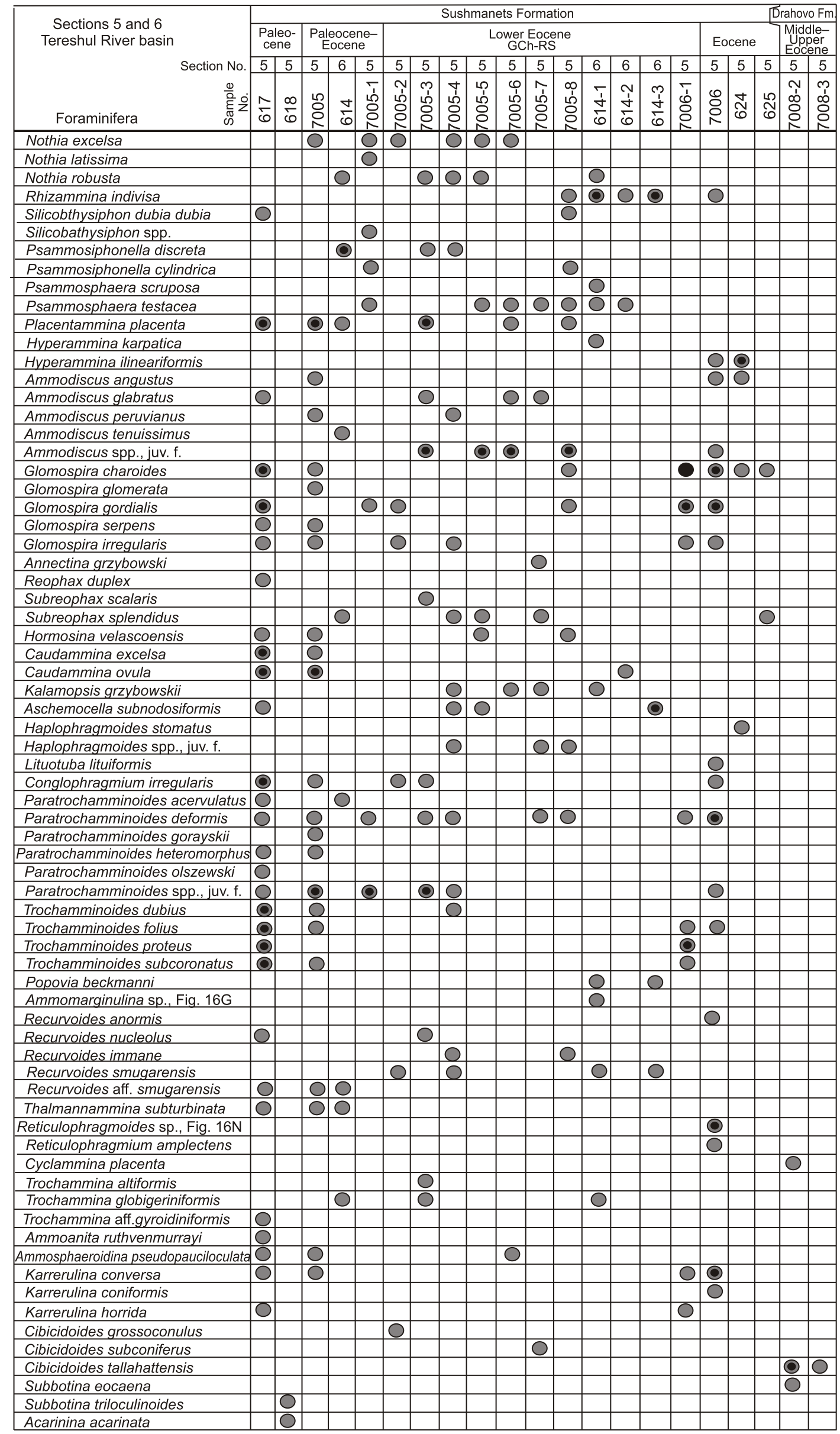

Fig. 13. Distribution of foraminifera in the Sushmanets Formation

Sections 5 and 6, Tereshul River basin, Monastyrets Nappe: GCh-RS - Glomospira charoides-Recurvoides smugarensis Zone 


\begin{tabular}{|c|c|c|c|c|c|c|c|c|c|c|c|c|c|c|c|c|c|c|}
\hline \multirow{4}{*}{\begin{tabular}{|c|} 
Sections $7,8,9$ \\
and samples 98-111, 98-112 \\
Teresva and Shopurka \\
River basins Section No. \\
\\
Foraminifera
\end{tabular}} & \multicolumn{18}{|c|}{ Sushmanets Formation } \\
\hline & \multicolumn{4}{|c|}{$\begin{array}{l}\text { Paleocene } \\
\mid \text { AA } \\
\end{array}$} & \multicolumn{4}{|c|}{$\begin{array}{c}\text { Lower Eocene } \\
\text { GCh-RS }\end{array}$} & \multicolumn{8}{|c|}{ Eocene } & \multicolumn{2}{|c|}{$\begin{array}{l}\text { Middle- } \\
\text { Upper } \\
\text { Eocene }\end{array}$} \\
\hline & 8 & 8 & 8 & 9 & 7 & 8 & 8 & 9 & 9 & 9 & 9 & 8 & 9 & 7 & 7 & 7 & & \\
\hline & $\begin{array}{l}\stackrel{p}{1} \\
0 \\
\stackrel{0}{0} \\
\stackrel{D}{~}\end{array}$ & 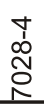 & 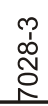 & $\begin{array}{l}\bar{c} \\
\grave{D} \\
\end{array}$ & চ & 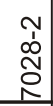 & 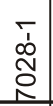 & $\begin{array}{l}N \\
\grave{N} \\
O\end{array}$ & $\begin{array}{l}m \\
\dot{1} \\
\stackrel{N}{ }\end{array}$ & 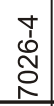 & $\begin{array}{l}0 \\
0 \\
\mathbb{D} \\
0 \\
\end{array}$ & $\stackrel{\infty}{\sim}$ & & స్ & ల్లి & $\begin{array}{l}\overline{1} \\
\text { है } \\
\text { లో }\end{array}$ & 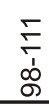 & $\frac{N}{\check{\sigma}}$ \\
\hline Nothia excelsa & () & & & () & & & (1) & O & () & O & 0 & () & & & $\mathrm{O}$ & & & \\
\hline Nothia latissima & 0 & & & & & & & & & & & & & & & & & \\
\hline Nothia robusta & () & & & & & & & & & & & & & & & & & \\
\hline Psammosiphonella discreta & $\bigcirc$ & & & & () & & & & & & & & & & & & & \\
\hline Psammosiphonella cylindrica & & & & P & & & & & & & & & & & & & & \\
\hline Rhizammina indivisa & & & & & O & & & & & & & & & & & & & \\
\hline Psammosphaera scruposa & & & & $\mathrm{O}$ & & & & & & & & & & $\bigcirc$ & O & & & \\
\hline Psammosphaera testacea & & & & $\mathrm{O}$ & & & & & & & & & & & & & & \\
\hline Placentammina placenta & $\bigcirc$ & & & & O & & $\mathrm{O}$ & $\bigcirc$ & & & & & & & & & & \\
\hline Hyperammina karpatica & & & & O & & & & & & & & & & & & & & \\
\hline Hyperammina lineariformis & & & & & & & & & & & & & & & O & & () & O \\
\hline Ammodiscus bornemmanni & & & & & & & & & & & & & & & 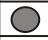 & & 0 & \\
\hline Ammodiscus infimus & O & & & & & & & & & & & & & & & & & \\
\hline Ammodiscus macilentus & & & & & & & 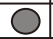 & & $\mathrm{O}$ & $\mathrm{O}$ & & & & & & & & \\
\hline Ammodiscus subangustus & & & & & & & & & & & & & & & & & & O \\
\hline Ammodiscus tenuissimus & & & & & & & & & & & & & & & & & & \\
\hline Glomospira charoides & $\bigcirc$ & & & 0 & & & & & & & & & & & & & & \\
\hline Glomospira gordialis & & & & O & & & & & & & & & & & & & & \\
\hline Glomospira irregularis & & & & & & & & & & & & & & & & & O & \\
\hline Subreophax nodulosus & & & & & O & & & & & & & & & & & & & \\
\hline Subreophax scalaris & $\bigcirc$ & & & & & & & & & & & & & & & & & \\
\hline Subreophax splendidus & & & & $\mathrm{O}$ & & & 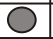 & & & O & & & & & & & & \\
\hline Hormosina trinitatensis & O & & & & & & & & & & & & & & & & & \\
\hline Hormosina velascoensis & O & & & & & & & & & $\mathrm{O}$ & & & & & & & & \\
\hline Caudammina excelsa & $\bigcirc$ & & & $\bigcirc$ & & & & & & & & & & & & & & \\
\hline Caudammina ovula & O & & & O & O & & & & & & & & & & & & & \\
\hline Ashemocella subnodosiformis & & & & & & & & & & $\mathrm{O}$ & & & & & O & & & \\
\hline Haplophragmoides horridus & & & & 0 & & & & & & & & & & & & & & \\
\hline Haplophragmoides parvulus & & & & & & & & & & & & & & & & & $\bigcirc$ & \\
\hline Conglophragmium irregularis & $\mathrm{O}$ & & & $\mathrm{O}$ & & & & & & & & & & & & & () & \\
\hline Paratrochamminoides spp., juv. f. & & & & () & & & & & & & & & & & $\bigcirc$ & & & \\
\hline Trochamminoides folius & O & & & & & & & & & & & & & & & & & \\
\hline Trochamminoides proteus & & & & 0 & & & & O & & & & & & & & & & \\
\hline Popovia beckmanni & & & & & & & & & & & & & & & & $\bigcirc$ & & \\
\hline Recurvoides anormis & & & & & & & & & & & & & & & $\mathrm{O}$ & & 0 & \\
\hline Recurvoides retroseptus & & & & $\mathrm{O}$ & & & & & & & & & & & & & & \\
\hline Recurvoides smugarensis & & & & & & $\mathrm{O}$ & & O & & & & & & & & & & \\
\hline Recurvoides aff. smugarensis & 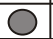 & & & & & & & & & & & & & & & & & \\
\hline Recurvoides walteri & & & & & & & & & & & & & & & & & O & \\
\hline Ammosphaeroidina pseudopauciloculata & & & & & & & & & & & & & & & O & & O & \\
\hline Praesphaerammina sp. Fig.16S & & & & & & & & & & & & & & & & & $\bigcirc$ & O \\
\hline Karrerulina coniformis & & & & & & & & & & & & & O & & & & & \\
\hline Karrerulina conversa & & & & $\mathrm{O}$ & & & & & & & & & & & & O & () & ( \\
\hline Cibicidoides grossoconulus & & & & & O & & & & & & & & & & & & & \\
\hline Cibicidoides subconiferus & & & & & $\mathrm{O}$ & & & & & & & & & & & & & \\
\hline Parasubbotina varianta & & & O & & & & & & & & & & & & & & & \\
\hline Subbotina triloculinoides & & O & () & & & & & $\mathrm{Or}$ & & Or & & & & & & & & \\
\hline Subbotina roesnaesensis & & & & & & & & & & $O$ & & & & & & & & \\
\hline Subbotina yeguaensis & & & & & & & & & & $\mathrm{O}$ & & & & & & & & \\
\hline Acarinina acarinata & & & () & & & & & $\mathrm{Or}$ & & & & & & & & & & \\
\hline Acarinina soldadoensis & & & () & & & & & $\mathrm{Or}$ & & & & & & & & & & \\
\hline Acarinina triplex & & & 0 & & & & & & & & & & & & & & & \\
\hline
\end{tabular}

Fig. 14. Distribution of foraminifera in the Sushmanets Formation

Sections 7, 8, 9 and samples 98-111, 98-112, Teresva and Shopurka River basins, Monastyrets Nappe: AA Acarinina acarinata Zone; GCh-RS - Glomospira charoides-Recurvoides smugarensis Zone 


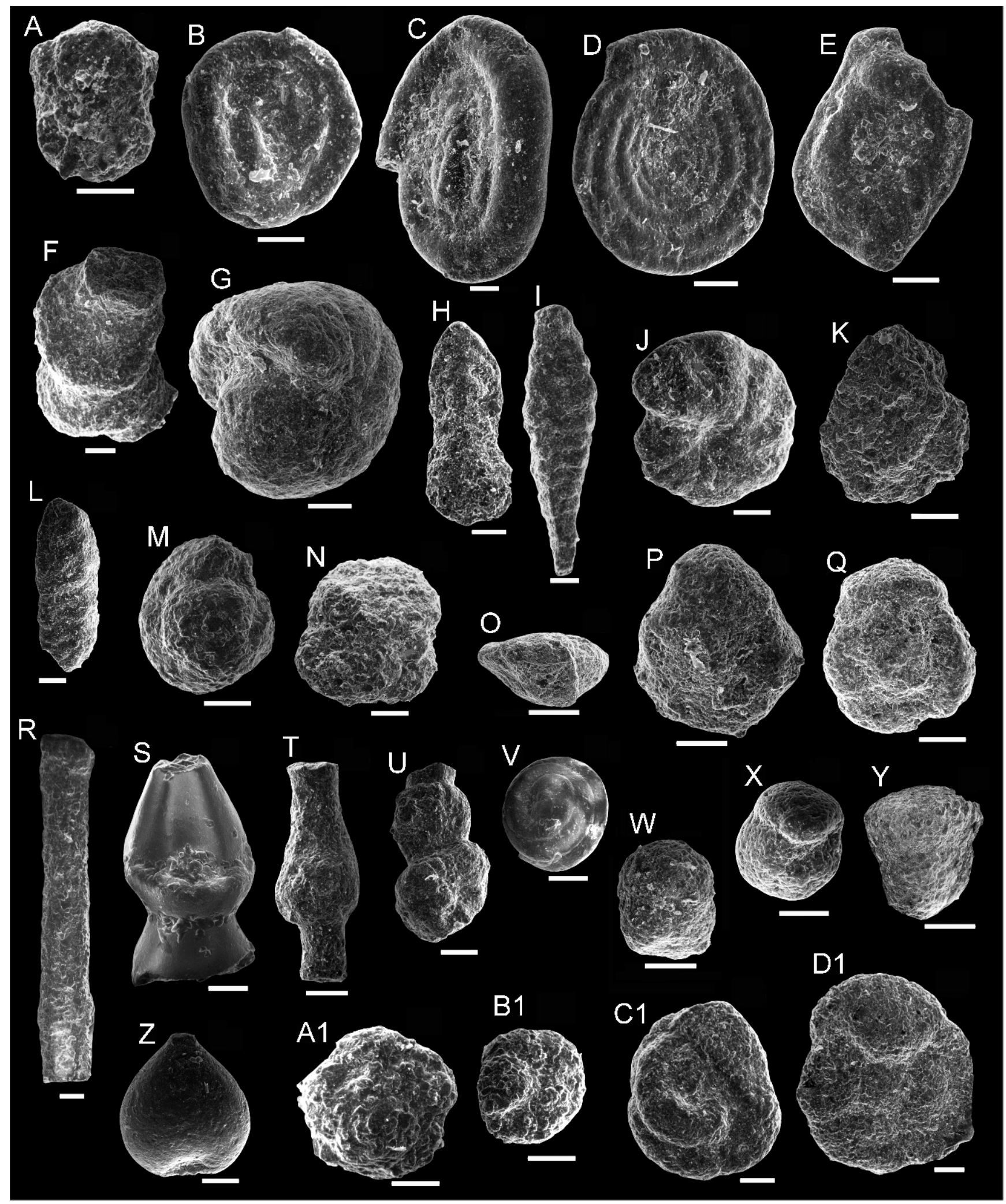

Fig. 15. Foraminifera from the Sushmanets Formation

Cretaceous-Paleocene taxa: A - Rugoglobigerina cf. macrocephala (sample 29-58); B - Glomospira diffundens (sample 29-57); C Annectina grzybowskii (sample 29-57); E - Rzehakina epigona (sample 29-57); G - Recurvoides retroseptus (sample 29-57); H, I Spiroplectammina spectabilis, macrospherical and microspherical forms (sample 29-57). Paleocene taxa: D - Ammodiscus angustus (sample 29-55); F - Subreophax scalaris (sample 29-55); J - Haplophragmoides walteri (sample 29-54/1); K - Popovia beckmanni (sample 29-54/1); L - Karrerulina horrida (sample 29-54); $\mathbf{M}$ - Recurvoides varius (sample 29-54); $\mathbf{N}$ - Trochammina globigeriniformis (sample 29-54/1); $\mathbf{O}$ - Morozovella angulata (sample 29-54/1); P, Q - Acarinina soldadoensis, umbilical and spiral view (sample 7028-3); $\mathbf{R}-$ Psammosiphonella cylindrica (sample 617); S - Hormosina velascoensis (sample 7005); T - Caudammina excelsa (sample 617); U Aschemocella subnodosiformis, initial part (sample 617); V - Glomospira charoides (sample 617); W - Subbotina aff. triloculinoides (sample 29-53); X - Acarinina acarinata (sample 7028-3); Y - Acarinina triplex (sample 7028-3); Z - Caudammina ovula (sample 617); A1 Ammoniata ruthvenmurrayi (sample 617); B1 - Trochammina aff. gyroidinaeformis (sample 617); C1 - Paratrochamminoides olszewski (sample 617); D1 - Trochamminoides subcoronatus (sample 617); scale bar $100 \mu \mathrm{m}$ 


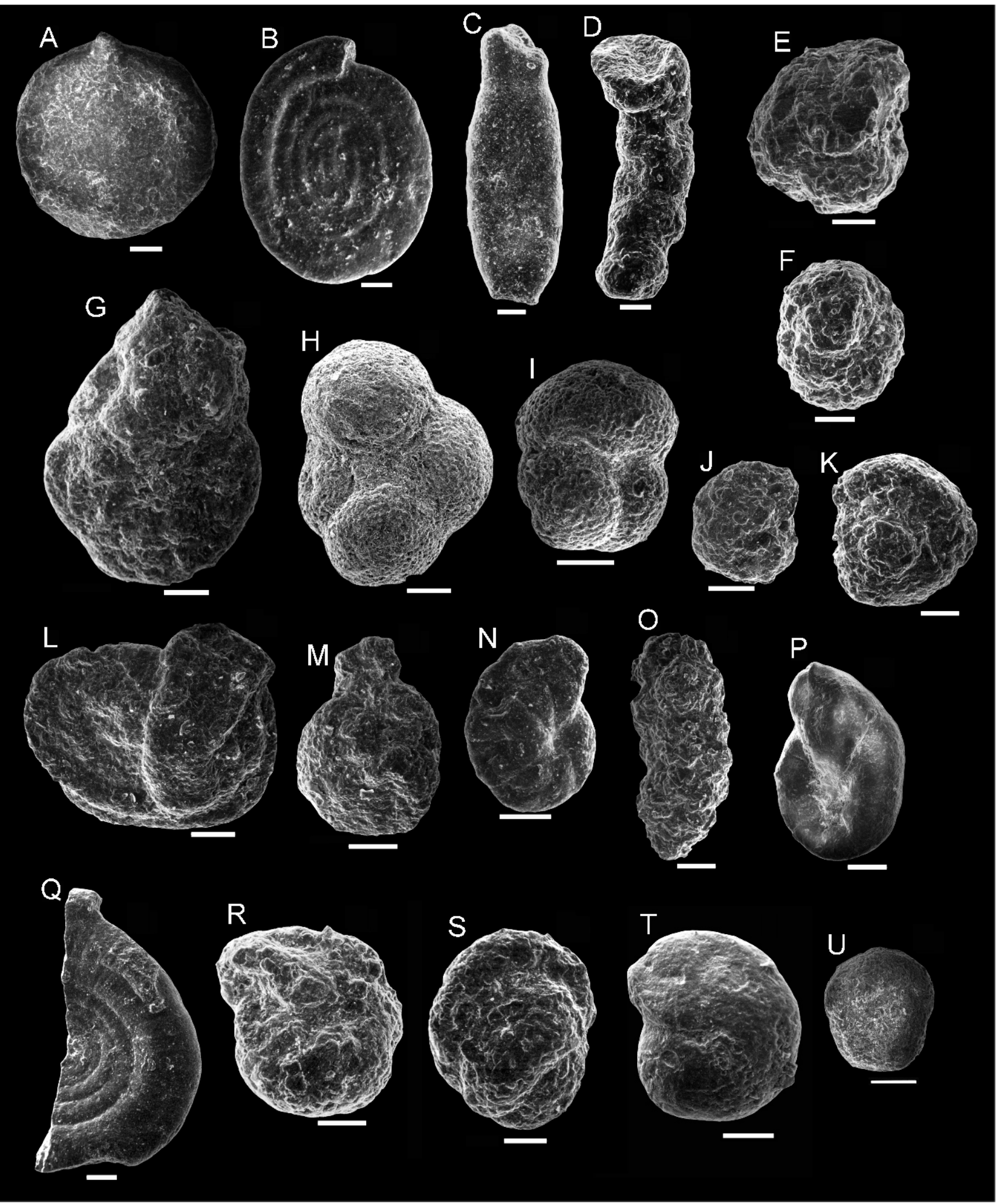

Fig. 16. Eocene foraminifera from the Sushmanets (A-S) and Drahovo (T and U) formations

A - Placentammina placenta (sample 7005-5); B - Annectina grzybowskii (sample 7005-7); C - Kalamopsis grzybowskii (sample 7005-7); D - Subreophax splendidus (sample 7026-4); E - Recurvoides smugarensis (sample 614-1); F - Thalmannammina subturbinata (sample 7005-4); G - Ammomarginulina sp. (sample 614-1); H - Subbotina yeguaensis (sample 7026-4); I - Subbotina roesnaesensis (sample 7026-4); J - Recurvoides anormis (sample 363); K - Recurvoides anormis (sample 98-11); L - Lituotuba lituiformis (sample 7006); $\mathbf{M}$ Trochamminoides folius (sample 7006); N - Reticulophragmoides sp. (sample 7006); O - Karrerulina conversa (sample 7006-1); $\mathbf{P}$ Haplophragmoides stomatus (sample 624); $\mathbf{Q}$ - Ammodiscus bornemanni (sample 98-111); $\mathbf{R}$ - Haplophragmoides parvulus (sample 98-111); S - Praesphaerammina sp. (sample 98-111); T - Cyclammina placenta (sample 7028-2); U - Acarinina rotundimarginata (sample 29-50); scale bar $100 \mu \mathrm{m}$ 


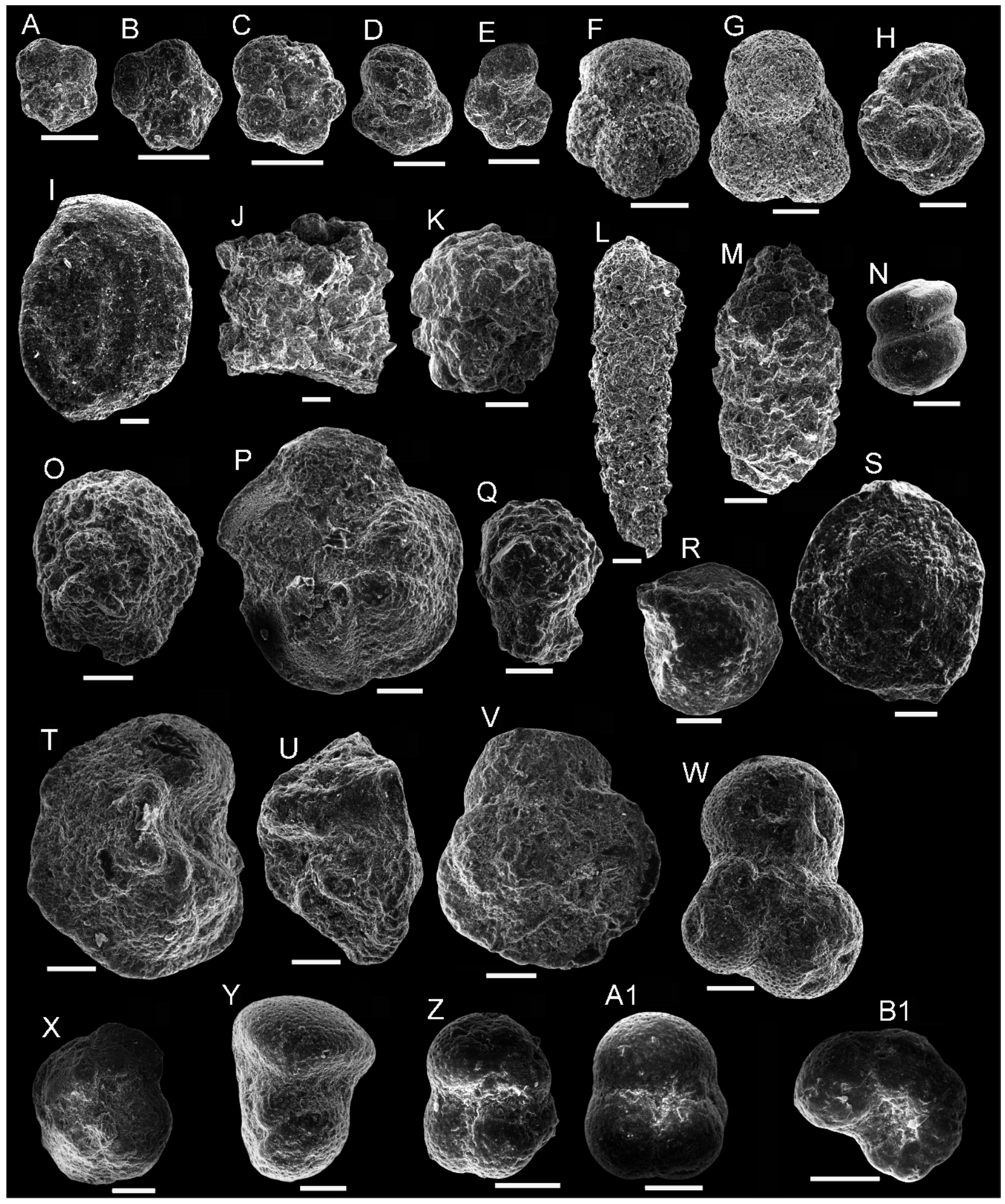

Fig. 17. Foraminifera from the Metova Formation

Paleocene taxa: A-C - Parvularugoglobigerina eugubina (sample 29-2); D - Eoglobigerina edita (sample 29-2); E - Praemurica aff. taurica (sample 29-2); F - Acarinina pseudotopilensis (sample 29-23); G - Subbotina triloculinoides (sample 29-23); H - Globigerina aquiensis (sample 7122); I - Annectina cf. grzybowskii (sample 29-23); J - Nothia sp. (sample 7121-4); K - Trochammina advena (sample 7121-4); L Textularia agglutinans (sample 7122); $\mathbf{M}$ - Karrerulina horrida (sample 7122); N - Glomospira charoides (sample 7122). Eocene taxa: $\mathbf{0}-$ Morozovella marginodentata (sample 7036-1); P - Morozovella aff. formosa (sample 7036-1); Q - Saccamminoides carpathicus (sample 7036-2); R - Nuttallides truempyi, umbilical view (sample 7036-2); S - Nuttallides truempyi, spiral view (sample 7036-4); T-V - Morozovella aragonensis, umbilical, peripheral and spiral view (sample 7036-3); $\mathbf{X}$ - Morozovella lensiformis (sample 7036-3); W - Parasubbotina inaequispira (sample 7036-2); Y - Acarinina bullbrooki (sample 7036-4); Z - Subbotina eocaena (sample 7036-4); A1 - Dipsidripella karpatica (sample 7036-4); B1 - Pseudohastigerina micra (sample 7036-4); scale bar $100 \mu \mathrm{m}$ 


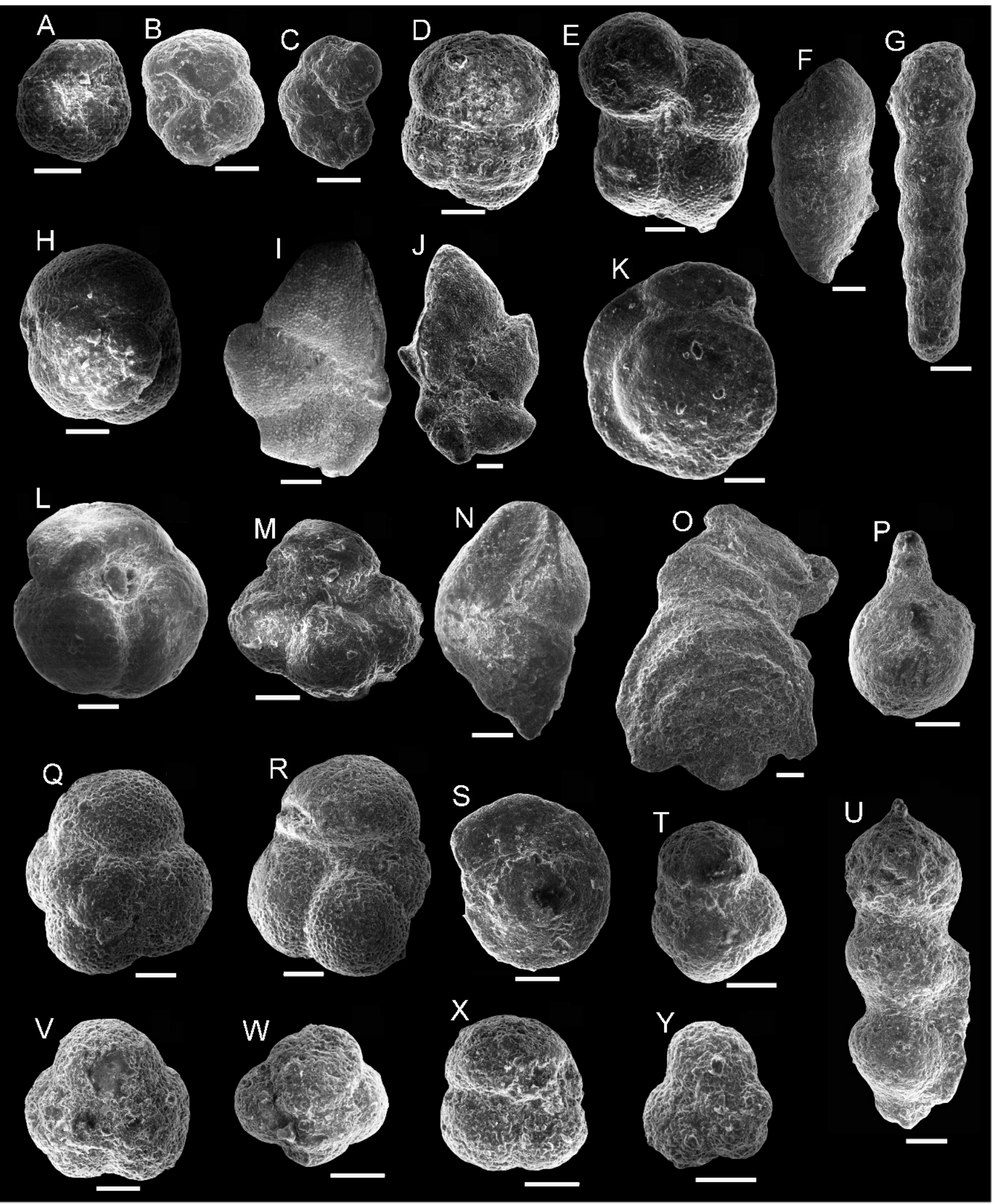

Fig. 18. Foraminifera from Metova Formation (continuous)

A - Acarinina rotundimarginata (sample 7036-5); B - Turborotalia cerroazulensis (sample 7036-5); C - Pseudohastigerina micra (sample 7036-5); D - Turborotalia frontosa (sample 7036-5); E - Subbotina hagni (sample 7036-5); F - Pleurostomella sp. (sample 7036-5); G Stilostomella sp. (sample 7036-5); H - Globigerinatheka index (sample 7036-5); I-J - Hantkenina liebusi (sample 7036-5); K - Nuttallides magnocamerata (sample 7036-5); L - Globigerinatheka index (sample 29-30); M - Catapsydrax dissimilis (sample 29-30); N Chiloguembelina compacta (sample 29-30); O - Vulvulina advena (sample 29-34); P - Lagena laevis (sample 29-34); Q - Subbotina corpulenta (sample 29-34); $\mathbf{R}$ - Dentoglobigerina galavisi (sample 29-34); $\mathbf{S}$ - Heterolepa biumbonata (sample 29-34); T - Globigerina officinalis (sample 29-35); U - Nodosaria praesoluta (sample 29-35); V - Dentoglobigerina tripartita (sample 29-35); W - Globoturborotalita ouachitaensis (sample 29-35); X - Subbotina droogeri (sample 29-35); Y-- Subbotina vialovi (sample 29-35); scale bar $100 \mu \mathrm{m}$ 
R e m a rks. - This zone was identified in grey marls (Globigerina Marl) of the uppermost part of the Metova Formation (section 3, sample 29-35, see Figs. 6 and 8).

The zonal assemblage is composed of numerous Subbotina vialovi (Fig. 18Y), Globigerina officinalis (Fig. 18T), S. droogeri (Fig. 18X), Globoturborotalita ouachitaensis (Fig. 18W), Dentoglobigerina galavisi, D. tripartita (Fig. 18V), rare Globigerinatheka cf. index and Pseudohastigerina micra. Abundant tests of planktonic foraminifera mainly of the genera Subbotina and Globigerina suggest that the grey marls of the uppermost part of the Metova Formation belong to the Globigerina Marl.

The Subbotina vialovi Zone is associated with the calcareous nannoplankton NP22 Zone and corresponds to the "undersilicic horizon" (lowermost part) of the Menilite Formation in the Outer Ukrainian Carpathians (Andreyeva-Grigorovich et al., 1985, 1987).

\section{BIOSTRATIGRAPHY BASED ON BENTHIC FORAMINIFERA}

The foraminiferal zonation of the Ukrainian Carpathians (Mjatliuk, 1970; Ivanik and Maslun, 1977; Andreyeva-Grigorovich et al., 1985; Hnylko and Hnylko, 2011, 2012) in accordance with the zonations of Geroch and Nowak (1984) and Olszewska (1997) is applied here.

Rare tests of poorly preserved Cretaceous planktonic foraminifera Rugoglobigerina cf. macrocephala (Fig. 15A) together with the Upper Cretaceous-Paleogene benthic species Silicobathysiphon gerochi, Kalamopsis grzybowskii, Ashcemocella grandis, Rhizammina indivisa and pyritised steinkerns of Chilostomella spp. are found at the beginning of section 4 in the sample 29-58. Numerous Spiroplectammina spectabilis (Fig. $15 \mathrm{H}, \mathrm{I}$ ), which compose $25 \%$ of the assemblage, together with the Upper Cretaceous-Paleogene taxa Rzehakina epigona (Fig. 15E), Glomospira diffundens (Fig. 15B), Annectina grzybowskii (Fig. 15C) and Recurvoides retroseptus (Fig. 15G) were found in sample 29-57 (lower part of section 4). Arguably, this assemblage corresponds to the Early Paleocene "Spiroplectammina acme" (sensu Kaminski and Gradstein, 2005).

\section{Rzehakina fissistomata sensu lato Zone, Paleocene}

D e f i $\mathrm{n}$ i t i o n.- The biostratigraphic interval between the FO of the nominate taxon Rzehakina fissistomata and the LO of Rzehakina fissistomata and/or Recurvoides varius.

$\mathrm{R}$ e $\mathrm{m}$ a r k s. - This zone was identified in the lower part of Sushmanets Formation (section 4, see Figs. 2 and 9).

The nominate taxon Rzehakina fissistomata was found in sample 29-55 (section 4). Numerous Recurvoides varius (samples 29-54/1, 29-54, see also Fig. 15M) and single specimens of planktonic Morozovella angulata (sample 29-54/1, see also Fig. 150) were found in the middle part of section 4 . The zonal assemblage (section 4, samples 29-55, 29-54/1, 29-54) contains Subreophax scalaris (Fig. 15F), Hormosina velascoensis, Haplophragmoides walteri (Fig. 15J), Popovia beckmanni (Fig. 15K) and Trochammina globigeriniformis (Fig. 15K) together with the Paleocene species mentioned.

Glomospira (charoides, serpens, gordialis), which composes $10 \%$ of the rich assemblage, together with Ammoanita ruthvenmurrayi (Fig. 15A1) of Campanian-Paleocene age (after Kaminski and Gradstein, 2005) and numerous Caudammina (excelsa, ovula) (see Fig. 15T, Z) as well as spe- cies belonging to the genera Ammodiscus, Paratrochamminoides and Trochamminoides, were found in the lower part of the lower variegated horizon (section 5, sample 617). The occurrence of relatively numerous Glomospira charoides was also established in the lower part of the lower variegated horizon in the sample 29-52 (section 4). The appearance of numerous Glomospira suggests an age close to the Paleocene/Eocene boundary (after Kaminski and Gradstein, 2005) for the lower variegated horizon. Probably, the lower part of the lower variegated horizon belongs to the Paleocene, which is supported by the presence of the planktonic species Subbotina triloculinoides and Acarinina acarinata (sample 618).

The Rzehakina fissistomata sensu lato Zone corresponds to the Rzehakina fissistomata Zone of the Polish Carpathians (Olszewska, 1997, see also Waśkowska-Oliwa, 2005, 2008) and the Czech Carpathians (Bubik, 1995).

$$
\begin{gathered}
\text { Glomospira charoides-Recurvoides smugarensis Zone, } \\
\text { Ypresian }
\end{gathered}
$$

D e fin it i o n. - The biostratigraphic interval of the frequent occurrence of the nominate taxon Recurvoides smugarensis between the disappearance of the Paleocene taxa and the occurrence of numerous Reticulophragmium amplectens. Abundant Glomospira charoides occur at different stratigraphic levels of this zone, mostly in the lower part of the zone (Hnylko and Hnylko, 2011, 2012).

$\mathrm{R}$ e $\mathrm{m}$ a r k s. - This zone was identified in the Sushmanets Formation (sections 4-9, see Figs. 2, 7 and 9). The lower boundary of the zone corresponds to the upper part of the lower variegated horizon of the Sushmanets Formation. The upper boundary probably is within the upper variegated horizon of this formation.

The occurrence of Recurvoides smugarensis (samples 7005-2 and 614-1, see also Fig. 16E) as well the FO of the characteristic taxon of the Lower Eocene of the Polish Carpathians, Saccamminoides carpathicus (sample 29-52, section 4), was fixed in the upper part of the lower variegated horizon.

The zonal assemblage (in the deposits inside between the two variegated horizons) is composed of Recurvoides smugarensis, Placentammina placenta (Fig. 16A), Ammodiscus glabratus, A. macilentus, Glomospira gordialis, G. irregularis, Subreophax splendidus (Fig. 16D), Kalamopsis grzybowskii (Fig. 16C), Conglophragmium irregularis and Thalmannammina subturbinata (Fig. 16F) as well as numerous juvenile forms of Ammodiscus. The planktonic species Subbotina yeguaensis (Fig. 16H) and Subbotina roesnaesensis (Fig. 16I) were found in this zone.

Abundant Glomospira charoides, which ranged from $70 \%$ (sample $7006-1$ ) to $30 \%$ (sample 7006) of foraminiferal specimens, was found at the bottom of the upper variegated horizon. The FO of Reticulophragmium amplectens together with numerous tests of Karrerulina conversa (Fig. 160) and Reticulophragmoides sp. (Fig. 16N) as well as Hyperammina lineariformis, Ammodiscus bornemanni, Lituotuba lituiformis (Fig. 16L), Recurvoides anormis, was found in sample 7006. This assemblage corresponds to the second "Glomospira Acme" (sensu Kaminski and Gradstein, 2005) and determines the age of the deposits as close to the Lower/Middle Eocene boundary.

Saccamminoides carpathicus (Fig. 17Q) and the calcareous benthic species Oridorsalis umbonatus, Cibicidoides grossoconulus, Nodosaria praesoluta, Nuttallides truempui 
(Fig. 17R), N. magnocamerata and Ellipsoglandulina labiata were found in the assemblages of the Morozovella aragonensis Zone (Upper Ypresian) in the Metova Formation (Section 1).

The Glomospira charoides-Recurvoides smugarensis Zone corresponds either to the Saccamminoides carpathicus Zone (after Geroch and Nowak, 1984) or both the Glomospira div. sp. Zone and the Saccamminoides carpathicus Zone (after Olszewska, 1997; see also Waśkowska-Oliwa, 2005 Waśkowska, 2008) of the Polish Carpathians as well as to the "Glomospira-Ammodiscus» Zone of the Slovakian Carpathians (Fusán, 1983). Abundant Glomospira occur in the Lower Eocene deposits of the Polish Carpathians (Olszewska, 1997; Waśkowska, 2015 with references therein).

The Reticulophragmium amplectens Zone was not identified in the sections studied. In the Ukrainian Carpathians, this zone corresponds to the Acarinina bullbrooki Zone according to Gruzman and Dabagyan (1979) and to the Acarinina rotundimarginata Zone according to Mjatliuk (1970) and Andreyeva-Grigorovich et al. (1985). Cyclammina placenta and Silicobathysiphon subdivisus as well as the calcareous benthic species Nodosarella subnodosa, Oridorsalis umbonatus, Nuttallides truempyi (Fig. 17S), Nuttallides magnocamerata (Fig. 18K), Stilostomella sp. (Fig. 18G) Pleurostomella alazanensis cubensis, Pleurostomella sp. (Fig. 18F), Chilostomella chilostomelloides, and Anomalinoides acutus were found in these planktonic zones in the Metova Formation (section 1, samples 7036-4 and 7036-5).

An assemblage with Haplophragmoides parvulus was found in the Sushmanets Formation (samples 98-111 and 98-112). This assemblage is composed of Haplophragmoides parvulus (Fig. 16R), Ammodiscus bornemanni (Fig. 16Q), Recurvoides anormis (Fig. 16K), R. walteri, Praesphaerammina sp. (Fig. 16S) and numerous Hyperammina lineariformis and Karrerulina conversa. Haplophragmoides parvulus is a characteristic species of the latest Middle Eocene-early Late Eocene in the Polish Carpathians according to Golonka and Waśkowska (2012, with references therein).

Numerous Cibicidoides tallahattensis together with Cyclammina placenta (Fig. 16T) and single specimens of Subbotina eocaena were determined in the Drahovo Formation (section 5, samples 7008-2 and 7008-3). Cibicidoides tallahattensis is typical of marls of the Outer Carpathian Popiele Formation (Mjatliuk, 1970) while the age of these marls is Bartonian to Early Rupelian according to nannoplankton data (Andreyeva-Grigorovich, 1999).

Vulvulina advena (Fig. 180), Nodosaria praesoluta (Fig. 18U), Nuttallides magnocamerata, Lagena laevis (Fig. 18P), Gyroidina soldanii, and Heterolepa biumbonata (Fig. 18S) were established in the Globigerina Marl in the both the planktonic Subbotina corpulenta Zone and the Subbotina vialovi Zone (Upper Priabonian-Lower Rupelian) in the Metova Formation (section 2, samples 29-34 and 29-35).

\section{FORAMINIFERAL BIOFACIES}

A biofacies of agglutinated foraminifera (1), a mixed planktonic-benthic biofacies (2) and a plankton-dominated biofacies (3) were determined by the percentage of planktonic to benthic specimens.

Biofacies of agglutinated foraminifera (1) is entirely composed of agglutinated forms, sometimes with a small admixture of calcareous foraminifera. This biofacies is present in the Sushmanets Formation (Fig. 9) and in the clastic deposits of the lower member of the Metova Formation (Fig. 8).
Sushmanets Formation. Representatives of the genera Nothia, Rhizammina, Psammosiphonella, Silicobathysiphon, Hyperammina, Ammodiscus, Glomospira, Rzehakina. Hormosina, Caudammina, Haplophragmoides, Trochamminoides, Paratrochamminoides, Popovia, Recurvoides, Thalmannammina, Trochammina and Karrerulina dominate in the biofacies. A firmly cemented test, siliceous composition, and lack of any calcareous component are characteristics of the foraminifera identified. The generic composition and morphological features suggest that this assemblage belongs to the deep-water agglutinated foraminiferal biofacies. Several foraminiferal assemblages can be distinguished in the biofacies (1).

The "Rzehakina" assemblage (Rzehakina Faunas sensu Kuhnt and Kaminski, 1989) was determined in mudstone intercalations of the Paleocene Flysch (section 4, see Fig. 9). Characteristics of the assemblage include: moderate diversity (20 species belonging to 15 genera); the predominance of rather large $(0.6-1 \mathrm{~mm})$ tests with fine-grained walls and smooth surfaces, represented by species of Silicobathysiphon, Glomospira, Annectina, Hormosina and Caudammina; rare presence of calcareous specimens.

The "Paratrochamminoides" assemblage (Paratrochamminoides Faunas sensu Kuhnt and Kaminski, 1989) was distinguished in red and green mudstone from the upper part of the Paleocene deposits of the Sushmanets Formation (sections 5, 8 and 9, see Fig. 9). Characteristics of this assemblage include: the absence of calcareous fossils; high diversity of agglutinated forms (approximately 40 species belonging to 20 genera); high contents of Trochamminoides (dubius, folius, proteus, subcoronatus) and Paratrochamminoides (acervulatus, deformis, gorayski, geteromorphus, olszewski) (up to $25 \%$ of the foraminiferal assemblage) as well as Glomospira (charoides, serpens, glomerata) (up to 15\%); the presence of Ammodiscus, Caudammina (ovula, excelsa), Thalmannammina, Karrerulina (conversa, horrida). The comparatively large size $(0.6-1 \mathrm{~mm})$ and fine- to medium-grained walls of the tests are typical of foraminifers from the green mudstone. Smaller size $(0.2-0.6 \mathrm{~mm})$, fine-grained walls and commonly smooth glossy surfaces of the tests are features of the foraminifers from the red mudstone.

The "Rhabdammina" assemblage ("Rhabdammina" Faunas sensu Kuhnt and Kaminski, 1989; slope flysch-type biofacies sensu Bubik, 1995) was identified in the Lower Eocene and Middle Eocene grey-green flysch of the Sushmanets Formation (sections 5-9, see Fig. 9). Characteristics of this assemblage are: a high content (approximately $40-90 \%$ of foraminiferal assemblage) of tubular tests of Nothia (excelsa, latissima, robusta), Psammosiphonella (discreta, cylindrica), Rhizammina indivisa, Hyperammina (karpatica, lineariformis), and Silicobathysiphon spp.; the predominance of moderate to large specimens with medium- to coarse grained wall structure; and a small admixture of calcareous foraminifers. Low diversity (4-8 species and genera) is characteristic of both the Early Eocene (sections 8 and 9) and Middle Eocene (sections 5 and 7) assemblages. Moderate diversity (approximately 30 species from 18 genera) and the frequent occurrence of specimens of the genus Paratrochamminoides are typical of Early Eocene assemblages in section 5 .

The "Glomospira" assemblage ("Glomospira facies" sensu Kaminski et al., 1989) was identified in the red mudstone of the upper variegated horizon of the Sushmanets Formation (section 5, samples 7006-1 and 7006). Characteristics of this assemblage include: the absence of calcareous fossils; a high percentage of Glomospira charoides $(70 \%$ in sample $7006-1)$ or Glomospira charoides and Ammodiscus (40\% in sample 7006 ) 
as well as Karrerulina conversa and Paratrochamminoides; a predominance of small tests $(0.2-0.6 \mathrm{~mm})$ with fine-grained walls and a smooth glossy surface. The "Glomospira" assemblage in the Sushmanets Formation corresponds to the "Glomospira facies" of the same age (boundary between the Lower and Middle Eocene) in the red pelites of the southern Labrador Sea (Kaminski et al., 1989).

Metova Formation. Biofacies (1) was distinguished in the upper part of the Paleocene deposits (sections 1 and 3 , see Fig. 8). Characteristics of the biofacies are: moderate diversity (18 species from 13 genera), the predominance of large, coarse-grained tests, in particular of the species Trochammina advena, Textularia agglutinans and Nothia sp. (Fig. 17J-L).

A mixed planktonic-benthic biofacies (2) was recognized in the Metova Formation (sections 1 and 3). In section 1 (Morozovella subbotinae Zone), the biofacies is made up of agglutinated foraminifera ( 50\%), plankton ( 40\%) and calcareous benthics ( 10\%). In section 3, the biofacies is composed of planktonic foraminifera (up to $30 \%$ ) and agglutinated benthics. Coarse-grained tests of Nothia sp., Trochammina advena, and Textularia agglutinans predominate among the agglutinated assemblage. Calcareous benthics are characterized by the genera Oridorsalis, Nodosaria, and Cibicidoides.

A biofacies of mainly planktonic foraminifera (3) was distinguished in green, red, and blue-grey marls of the Metova Formation (sections 1 and 3; see Fig. 8) and locally in green marls of the Sushmanets Formation (section 8; see Fig. 9). The biofacies is characterized by a predominance of planktonic specimens $(>65 \%)$ over benthic ones.

In the green and red marls of the Metova Formation (Morozovella aragonensis Zone, Acarinina bullbrooki Zone and Acarinina rotundimarginata Zone), biofacies (3) consists of plankton (70-85\%), calcareous benthics (3-18\%) and agglutinated benthics (9-15\%). Calcareous benthics are represented mainly by the genera Nuttallides, Chilostomella, Oridorsalis, Nodosaria, Pleurostomella, Stilostomella, tests are of large size $(0.6-1 \mathrm{~mm})$ and have a finely-perforate smooth wall.

In the blue-grey marls (Globigerina Marl) of the Metova Formation, biofacies (3) contains plankton $(75 \%)$, calcareous benthics $(>20 \%)$ and an insignificant number of agglutinated benthics. Calcareous benthics are represented by the genera Nuttallides, Nodosaria, Stilostomella, Gyroidina, Lagena, Heterolepa and Cibicidoides.

Plankton foraminifers (100\% of taphocenoses) were found in green marls (Acarinina acarinata Zone) distributed locally in the green-grey thin-bedded flysch of the Sushmanets Formation (section 8, sample 7028-3). Such characteristics as: a much smaller number of foraminifera in the sample; low diversity (4 species belonging to 4 genera); small size and less expressive sculpture of the test wall, distinguish them from the foraminifers of the Metova Formation.

\section{DISCUSSION}

\section{PALAEOBATHYMETRY}

Paleocene-Eocene Monastyrets succession (Sushmanets and Drahovo formations). The Sushmanets Formation is characterized almost entirely by deep-water agglutinated foraminifers of biofacies (1). The foraminiferal assemblages distinguished in the Sushmanets Formation indicate the following environments (according to Kuhnt and Kaminski, 1989): the "Rzehakina" assemblage (Paleocene flysch deposits) points to continental slope conditions; the "Rhabdammina" assemblage
(Eocene flysch deposits) indicates lower slope water depths $(1500->2500 \mathrm{~m})$ and the "Paratrochamminoides" assemblage (variegated shales, Paleocene-Eocene boundary) suggests abyssal depths below the carbonate compensation depth (CCD). Most foraminifers of the "Paratrochamminoides" assemblage, identified in the red mudstone, belong to the "Type-B" assemblage sensu Gradstein and Berggren (1981) and Kaminski et al. (1988) based on morphological features (small size, fine-grained wall, smooth surface of tests). Agglutinated foraminifera of the "Type-B" assemblage, distributed in the Late Cretaceous-Paleogene red pelites of the Atlantic Ocean, characterise deep-water pelagic sedimentatary environments below the CCD (Gradstein and Berggren, 1981; Kaminski et al., 1988). The "Glomospira" assemblage (according to Kaminski et al., 1989) represents a period of lowered sedimentation rate.

Biofacies (3) locally found in the green marls (section 8) indicates the presence of underwater elevations with pelagic carbonate sedimentation in the deep-water Early Eocene Monastyrets Basin.

Impoverished foraminifera assemblages of the Drahovo Formation make it impossible to distinguish biofacies. However, the lack of deep-water agglutinated foraminifers and the presence of calcareous tests of the genera Cibicidoides, Subbotina and Acarinina in the Drahovo Formation suggest shallowing of the Drahovo sedimentary basin in comparison with the Sushmanets basin.

The sedimentological data support the conclusions based on foraminifera, indicating a deep-water depositional environment. The Sushmanets Formation is represented by thick $(>1000 \mathrm{~m})$ typical flysch deposits characterized by classic Bouma intervals that suggest accumulation by turbidity currents and background hemipelagic (red and green mudstones) deposition. Similarly thick accumulations of turbidites may be formed, most likely, at the base of the continental slope.

Paleocene-Lowermost Oligocene Vezhany succession (Metova Formation). Biofacies (1), (2), and (3) were distinguished in the deposits of the Metova Formation (Fig. 8). Plankton-dominated biofacies (3), identified in the marls ranging in age from Early Eocene up to earliest Oligocene, indicates hemipelagic sedimentary environments at bathyal depths acording to existing models (Murray, 1976, Gorbachik et al., 1996). The great quantity of calcareous foraminifers in the deposits and the predominance of planktonic specimens suggests these environments. Calcareous benthics of the genera Nuttallides, Chilostomella, Oridorsalis, Nodosaria, Ellipsoglandulina, Pleurostomella, Stilostomella, Gyroidina, and Lagena found in biofacies (3) are mostly regarded as deep-water taxa of the bathyal zone (Olszewska, 1984; Morkhoven et al., 1986; Olszewska et al., 1996; Waśkowska-Oliwa, 2005). Good preservation of the calcareous tests indicates depths above the foraminiferal lysocline.

The agglutinated foraminifers of biofacies (1) and of mixed biofacies (2) from the Metova Formation are characterized by similar species composition and morphological features (coarse-grained wall). These agglutinated foraminifers in biofacies (2) are placed together with numerous planktonic specimens. This fact probably indicates similar bathyal depths of sedimentation of the clastic and marble deposits of the Metova Formation.

The sedimentological data support the conclusions based on foraminifera, indicating a bathyal environment. The relatively thin (100-200 m in thickness) marly-clastic deposits of the Metova Formation do not show turbidite textures with Bouma intervals. These deposits could have been formed by hemipelagic sedimentation with a small additional supply of terrigenous material in the area of the continental slope. 


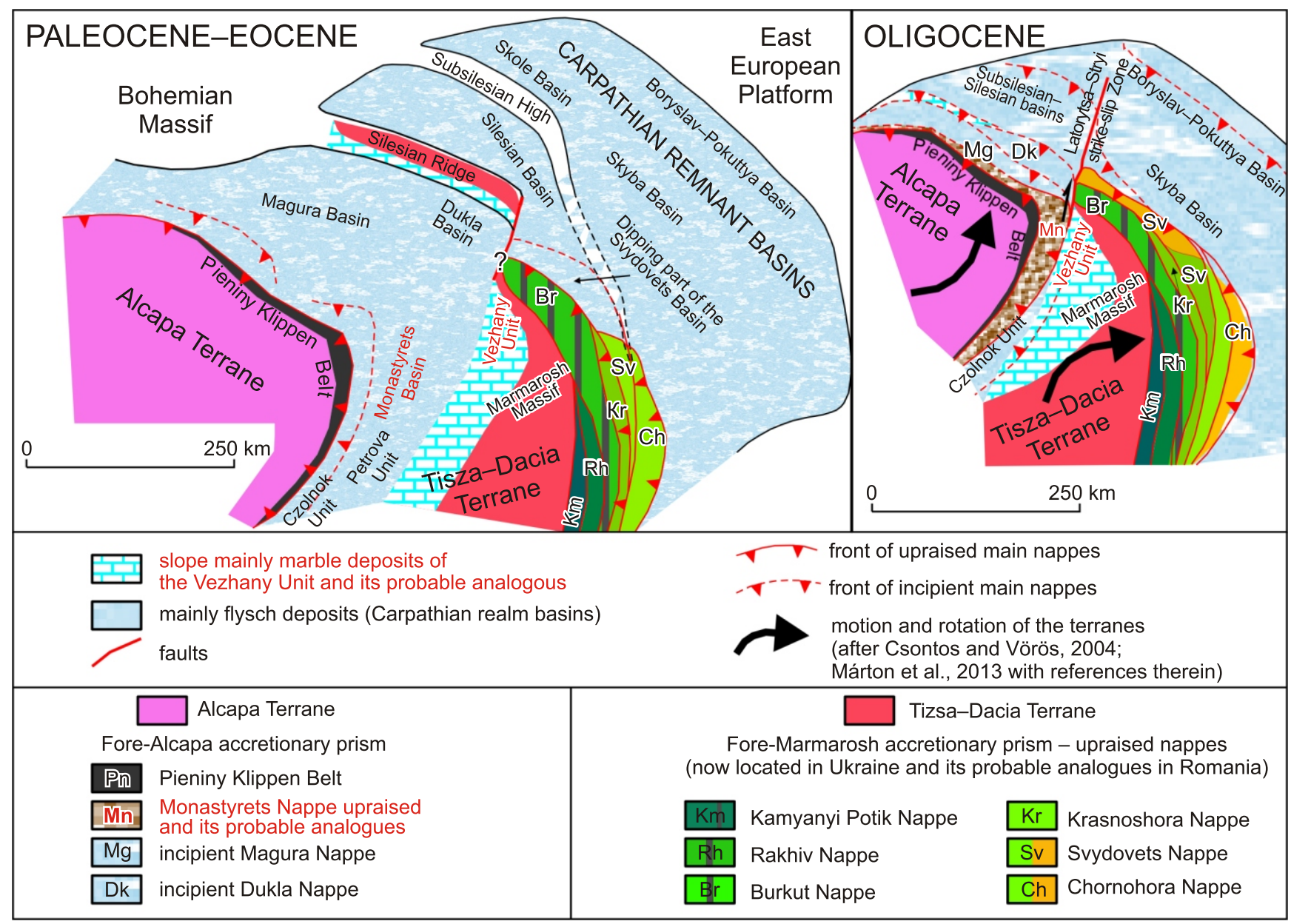

Fig. 19. General position of the Vezhany and Monastyrets units in Paleocene/Eocene and Oligocene times

Location of terranes approximately according to Csontos and Vörös (2004). Schematic reconstructions of the Carpathian realm based on the restorations of Burchfiel (1980), Oszczypko et al. (2005), Oszczypko (2006), Ustaszewski et al. (2008) and accretionary flysch prisms after Balla (1982), Gnylko (1999), Merten et al. (2010), Hnylko (2011b, c), Hnylko and Generalova (2014) and Hnylko et al. (2015), modified

\section{POSITION OF THE PALAEOBASINS}

Reconstructions of the geological history of the Carpathian region (Burchfiel, 1980; Săndulescu, 1988; Golonka et al. 2000; Csontos and Vörös, 2004; Oszczypko, 2006; Ślączka et al., 2006; Uchman et al., 2006; Schmid et al., 2008; Golonka, 2011; and references therein) including the Ukrainian Carpathians (Gnylko, 1999; Hnylko, 2011c, 2012; Hnylko and Generalova, 2014; Hnylko et al., 2015) may be supplemented by possible restorations of the palaeogeographic and tectonic position of the Monastyrets and Vezhany palaeobasins. Apparently, the Monastyrets deep-water flysch Basin together with its probable continuations: the Petrova-Leorgina-Wild Flysch basins (Oszczypko et al., 2005 and references therein) and the Szolnok Basin (Balla, pers. comm., see also Balla, 1982; Nagymarosy and Baldi-Beke, 1993) may belong to the deep-water seaway between the Tisza-Dacia and Alcapa terranes (Figs. 1 and 19). The probable prolongation of the Monastyrets Unit into the Magura Unit in present-day structure (Byzova and Beer, 1974; Oszczypko et al., 2005) suggests that the Monastyrets and Magura sedimentary palaeobasins were connected. The Magura Basin belongs to the Outer Carpathian flysch basins, thus the Monastyrets Palaeobasin could belong to a branch of the Outer Carpathian basins. This branch was wedged between the Tisza-Dacia and Alcapa terranes (Fig. 19).

The assemblages of smaller foraminifera and sedimentological data indicate that the Paleocene-lowermost Oligocene deposits of the Vezhany Basin were deposited in bathyal environments. Now these sediments likely belong to the uprooted cover of the Marmarosh Massif - part of the Tisza-Dacia Terrane. Therefore, they could have been deposited on the slope of the Tisza-Dacia Terrane (microcontinent). This slope had been inclined to the south-west towards the deep-water Monastyrets flysch Basin as indicated by the present-day tectonic position: the Monastyrets Nappe thrust over the Vezhany Nappe from the south-west.

The lack of post-Eocene strata in the Monastyrets succession as well as the thrust of the Monastyrets Nappe over the Oligocene deposits of the Vezhany Unit can be related to the closure of the deep-water flysch basin (or part of this basin) between the Alcapa and Tisza-Dacia terranes (Fig. 19). 


\section{CONCLUSIONS}

In the inner (southwestern) part of the Ukrainian Carpathians, two types of Paleogene sedimentary succession differing by their foraminiferal composition and lithofacies can be distinguished. The first type is developed in the Vezhany Nappe (Unit) and the second one is represented in the Monastyrets Nappe (Unit). The Paleocene-lowermost Oligocene succession of the Vezhany Nappe consists of "non-flysch" thin (100-200 m in thickness) marly-clastic calcareous deposits of the Metova Formation with a high content of planktonic foraminifera. The Paleocene-Eocene succession of the Monastyrets Nappe is represented by thick $(\sim 1700 \mathrm{~m}$ in thickness) typical flysch deposits of the Sushmanets Formation with a high content of agglutinated foraminifera, and overlying the Drahovo Formation.

The Parvularugoglobigerina eugubina Zone (Lower Danian), Acarinina acarinata Zone (Upper Thanetian), Morozovella subbotinae Zone and Morozovella aragonensis Zone (Ypresian), Acarinina bullbrooki Zone and Acarinina rotundimarginata Zone (Lutetian), Subbotina corpulenta Zone and Subbotina vialovi Zone (Upper Priabonian-Lower Rupelian) based on planktonic foraminifera as well as the Rzehakina fissistomata sensu lato Zone (Paleocene), Glomospira charoides-Recurvoides smugarensis Zone (Ypresian) and an assemblage with Haplophragmoides parvulus (latest Middle Eocene-early Late Eocene) based on agglutinated foraminifera were identified in these deposits of the Monastyrets and Vezhany units.

Three biofacies of: agglutinated foraminifera (1); mixed planktonic-benthic biofacies (2); and plankton-dominated biofacies (3) were determined in the Paleocene-lowermost Oligocene deposits of the Monastyrets and Vezhany units. Biofacies (1), distributed in the flysch deposits of the Sushmanets Formation, is represented by deep-water agglutinated foraminifera and contains the foraminiferal assemblages:
"Rzehakina", "Rhabdammina", "Paratrochamminoides" (according to Kuhnt and Kaminski, 1989) and "Glomospira" (according to Kaminski et al., 1988) identified on the basis of the generic composition and morphological features of the microfauna. The "Rzehakina", "Rhabdammina", "Paratrochamminoides" assemblages indicate depositional depths corresponding to the lower part of the continental slope to the abyssal environment below the CCD. The "Glomospira" assemblage represents a period of lowered sedimentation rate (according to Kaminski et al., 1989).

The insignificant quantity of deep-water agglutinated foraminifers and the presence of calcareous fauna in the Drahovo Formation suggest a shallowing of the sedimentary palaeobasin. The generic composition and morphological features of both the prevailing planktonic and smaller number of benthic foraminifera, which compose biofacies (3) distributed in the marls of the Metova Formation, suggest hemipelagic sedimentary environments at bathyal depths above the foraminiferal lysocline.

The Monastyrets Palaeobasin could belong to a branch of the Outer Carpathian deep-water flysch basins wedged between the Tisza-Dacia and Alcapa terranes (microcontinents). The Vezhany bathyal Basin was located on the slope of the Tisza-Dacia Terrane.

Acknowledgements. We are very grateful to Prof. M. Kaminski, Dr. A. Waśkowska, anonymous reviewers and the scientific editor Prof. T.M. Peryt for their constructive comments and useful remarks. The authors are very grateful to Prof. A.S. Andreyeva-Grigorovich for helpful advice and scientific consultations as well as to the Chief Geologist of the Geological Mapping Department of the Transcarpathian Geological Expedition, B.V. Matskiv, for shared geological fieldwork and useful discussions. We thank L.P. Bratus for assistance in the processing of samples and Y.R. Datsuk for photographing the foraminifera.

\section{REFERENCES}

Andreyeva-Grigorovich, A.S., 1999. Biostratigraphic correlations of the Paleogene deposits of the Ukrainian Carpathians and Crimea-Bakhchisarai area using nannoplankton and dinocysts. Geologica Carpathica, 50: 10-12.

Andreyeva-Grigorovich, A.S., Vialov, O.S., Gavura, S.P., Gruzman, A.D., Dabagyan, N.V., Danysh, V.V., Ivanik, M.M., Kulchitskiy, Ya.O., Lozynyak, P.Yu., Maslun, N.V., Petrashkevich, M.Y., Ponomaryova, L.D., Portnyagina, L.A., Smirnov, S.E., Sovchyk, Ya.V., 1985. Regional stratigraphic scheme of the Paleogene deposits of the Ukrainian Carpathians (in Russian with English summary). Paleontologicheskiy Sbornik, 22: 88-89.

Andreyeva-Grigorovich, A.S., Gruzman, A.D., Lozynyak, P.Yu., Smirnov, S.E., 1987. Key sections of the boundary layers of the Eocene-Oligocene of the Dukla and Marmarosh zones (in Russian with English summary). Paleontologicheskiy sbornik, 24 33-38.

Andreyeva-Grigorovich, A.S., Hnylko, O.M., Hnylko, S.R., 2012. Cretaceous-Paleocene boundary in the deposits of the Vezhany Nappe (Marmarosh Klippen Zone) of the Inner Ukrainian Carpathians (in Ukrainian). In: Paleontological research in improving the Phanerozoic stratigraphic schemes: XXXIV session of the Paleontological Society of NAS of Ukraine, Dnipropetrovsk, 28-31 May 2012: 66-67. Kyiv.
Balla, Z., 1982. Development of the Pannonian basin basement through the Cretaceous-Cenozoic collision: a new synthesis. Tectonophysics, 88: 61-102.

Berggren, W.A., Kent, D.V., Swisher, III, C.C., Aubry, M.P., 1995 A revised Cenozoic geochronology and chronostratigraphy. SEPM Special Publication, 54: 129-212.

Bolli, H.M., 1957. Planktonic foraminifera from the Eocene Navet and San Fernando formations of Trinidad, B.W.I. United States National Museum Bulletin, 215: 155-172.

Bubik, M., 1995. Cretaceous to Paleogene agglutinated foraminifera of the Bilé Karpaty unit (West Carpathians, Czech Republik). Grzybowski Foundation Special Publication, 3: 71-116.

Bugrova, E.M., ed., 2005. Practical guidebook of Microfauna. Vol. 8. Cenozoic Foraminifera (in Russian). VSEGRI Press. St. Peterburg.

Burchfiel, B.C., 1980. Eastern European Alpine System and the Carpathian orocline as an example of collision tectonics. Tectonophysics, 63: 31-61.

Byzova, S.L., Beer, M.A., 1974. Main features of the tectonics of the Soviet part of the Flysch Carpathians (in Russian). Geotektonica, 6: 82-94. 
Csontos, L., Vörös, A., 2004. Mesozoic plate tectonic reconstruction of the Carpathian region. Palaeogeography, Palaeoclimatology, Palaeoecology, 210: 1-56.

Dabagyan, N.V., Kruglov, S.S., Smirnov, S.E., 1965. Lithology and stratigraphy of the Cretaceous and Paleogene cover of the Transcarpathian Klippen Zone (in Russian). Trudy UkrNIGRI 14: 78-86.

Dabagyan, N.V., Kruglov, S.S., Smirnov, S.E., 1966. Stratigraphy scheme of the Cretaceous and Paleogene deposits of the Transcarpathian klippen (in Russian). Byuleten Moskovskogo Obshchestva ispytateley prirody. Otdeleniye geologii. 2: 84-93.

Darakchieva, S.H., 1999. Atlas of the Tertiary Small Foraminifera of the Bulgaria (in Bulgarian). Sofia.

Fusán, O., ed., 1983. Stratigraphic dictionary of the Western Carpathians. Vol. I (in Slovakian). Geologický Ústav Dionýza Štúra. Bratislava.

Geroch, S., Nowak, W., 1984. Proposal of zonation for the Late Tithonian-Late Eocene, based upon arenaceous Foraminifera from the Outer Carpathians, Poland. In: Benthos '83 (ed. H.J. Oertli): 225-239. 2nd International Symposium on Benthic Foraminifera Pau (France), April 11-15, 1983. Elf Aquitane ESSO REP and TOTAL CFP, Pau and Bordeaux.

Gnylko, O., 1999. Cretaceous evolution of the Fore-Marmarosh flysch basins (Ukrainian Carpathians). Geologica Carpathica, 50: $26-27$.

Golonka, J., 2011. Evolution of the Outer Carpathian Basins. Grzybowski Foundation Special Publication, 17: 3-14

Golonka, J., Waśkowska, A., 2012. The Beloveža Formation of the Raca Unit in the Beskid Niski Mts. (Magura Nappe, Polish Flysch Carpathians) and adjacent parts of Slovakia and their equivalents in the western part of the Magura Nappe; remarks on the Beloveža Formation - Hieroglyphic Beds controversy. Geological Quarterly, 56 (4): 821-832.

Golonka, J., Oszczypko, N., Ślączka, A., 2000. Late Carboniferous-Neogene geodynamic evolution and paleogeography of the circum-Carpathian region and adjacent areas. Annales Societatis Geologorum Poloniae, 70:107-136

Golyev, B.T., 1982. Stratigraphic distribution of nummulitid and their significance for the zonal division of the Paleogene. Abstract of the Dissertation for degree of Doctor of Geological-Mineralogical Sciences (in Russian), Leningrad.

Gorbachik, T.N., Dolitskaya, I.V., Kopayevich, L.F., Pirumova M.G., 1996. Micropalaeontology. Textbook (in Russian). MGU Press, Moskva.

Gradstein, F.M., Berggren, W.A., 1981. Flysch-type agglutinated foraminifera and the Maastrichtian to Paleogene history of the Labrador and North Seas. Marine Micropaleontology, 6: 211-268.

Gradstein, F.M., Ogg, J.G., Smith, A.G., eds, 2004. Geologic Time Scale 2004. Cambridge University Press, Cambridge.

Gruzman, A.D., Dabagyan, N.V., 1979. Planctonic foraminiferal zonations of the Paleocene and Eocene in the southern part of the Ukrainian Carpathians (in Russian with English summary) Paleontologicheskiy Sbornik, 16: 30-34.

Hnylko, O.M., 2011a. On the shear zone in the western part of the Ukrainian Carpathians (in Ukrainian with English summary). Heolohiya i Heokhimiya Horyuchykh Kopalyn, 156-157: 68-80.

Hnylko, O.M., 2011b. Tectonic zoning of the Carpathians in terms of the terrane tectonics. Section 1. Main units of the Carpathian Building (in Ukrainian with English summary). Geodynamika, 10: 47-57.

Hnylko, O.M., 2011c. Terrane analysis and geological evolution of the Carpathians (in Ukrainian with English summary). Visnyk Lvivskoho Derzhavnoho Universytety, Seria "Heolohiya", 25: 174-188.

Hnylko, O.M., 2012. Tectonic zoning of the Carpathians in terms of the terrane tectonics Article 2. The Flysch Carpathian - ancient accretionary prism (in Ukrainian with English summary). Geodynamika, 12: 67-78.

Hnylko, O.M., Generalova, L.V., 2014. Tectonic-sedimentary evolution of the Fore-Marmarosh accretionary prism of the Ukrai- nian Carpathians (in Russian with English summary). Vestnik of Saint Petersburg University, Series 7, Geology, Geography: 5-23.

Hnylko, O., Hnylko, S., 2011. Stratigraphy and sedimentary environments of the Eocene flysh from the Krosno (Silesian) Nappe of the Ukrainian Carpathians (in Ukrainian with English summary). Heolohichnyy zhurnal, 2: 12-24.

Hnylko, O.M., Hnylko, S.R., 2012. Stratigraphy of the Paleocene-Eocene flysch from the Svydovets Nappe of the Ukrainian Carpathians (in Ukrainian with English summary). Heolohichnyy Zhurnal, 3: 59-67.

Hnylko, O.M., Hnylko, S.R., Generalova, L.V., 2015. Formation of the structure of the Klippen Zones and the Interklippen Flysch of the Inner Ukrainian Carpathians - result of convergense and collission of microcontinental terranes (in Russian with English summary). Vestnik of Saint Petersburg University, Series 7, Geology, Geography: 4-24.

Hnylko, S., 2008. On the distribution of small Paleogene foraminifers in the deposits of the Sushmanets Formation (Marmarosh Zone, Ukrainian Carpathians) (in Ukrainian with English summary). Heolohiya i Heokhimiya Horyuchykh Kopalyn, 142: 33-43

Hnylko, S.R., Hnylko, O.M., 2010. Early Eocene agglutinated foraminifers and sedimentological features of the flysch from Monastyrets and Skyba nappes of the Ukrainian Carpathians (in Ukrainian with English summary). Heolohiya i Heokhimiya Horyuchykh Kopalyn, 150: 43-59.

Hnylko, S.R., Hnylko, O.M., 2013. Stratigraphy, foraminiferal biozonal subdivision and sedimentary environments of the Paleocene-Eocene deposits of the Vezhany Nappe from the Inner Carpathians (in Ukrainian with English summary). Zbirnyk naukovykh prats Instytutu heolohichnykh nauk NAN Ukrayiny, 6: 90-97

Horvath, F., Galacz A., eds., 2006. The Carpathian-Pannonian Region: A Reviev of Mesozoic-Cenozoic Stratigraphy and Tectonics. Vol. 1. Stratigraphy. Vol. 2. Geophysics, Tectonics, Facies, Paleogeography. Publ. Hantken Press, Budapest.

Ivanik, M.M., Maslun, N.V., 1977. Siliceous Microorganisms and Their Application for the Dismemberment of the Paleogene Deposits of the Precarpathians (in Russian). Naukova Dumka, Kiev.

Kaminski, M.A., Geroch, S., 1993. A revision of foraminiferal species from the Grzybowski collection. Grzybowski Foundation Special Publication, 1: 239-323.

Kaminski, M.A., Gradstein F.M., 2005. Atlas of Paleogene cosmopolitan deep-water agglutinated foraminifera. Grzybowski Foundation Special Publication, 10: 1-547.

Kaminski, M.A., Gradstein, F.M., Berggren, W.A., Geroch, S. Beckmann, J.P., 1988. Flysch-type agglutinated foraminiferal assemblages from Trinidad: Taxonomy, stratigraphy ŕnd paleobathymetry. Abhandlungen der Geologischen Bundesanstalt, 41: 155-227.

Kaminski, M.A., Gradstein, F.M., Berggren, W.A., 1989. Paleogene benthic foraminifer biostratigraphy and paleoecology at Site 647, Southern Labrador Sea. Proceeding of the Ocean Drilling Program, Scientific Results, 105: 705-730.

Khalilov, D.M., 1948. The Stratigraphy of the Upper Cretaceous and Paleogene Deposits of the Small Balkhan According to the Fauna of Foraminifera (in Russian). Aznefteizdat, Baku.

Kovač, M., Nagymarosy, A., Oszczypko, N., Ślączka, A., Csontos, L., Marunteanu, M., Matenco, L., Márton, M., 1998. Palinspastic reconstruction of the Carpathian-Pannonian region during the Miocene. In: Geodynamic development of the Western Carpathians (ed. M. Rakus): 189-217. Geological Survey of Slovak Republic, Bratislava.

Kruglov, S.S., ed., 1986. Tectonics of the Ukrainian Carpathians (explanatory report to the Tectonic Map of the Ukrainian Carpathians, scale 1:200 000) (in Russian). Naukova Dumka, Kiev.

Kryvin, A.L., 1960. Features of geological structure of the northwest margin of the Marmarosh Massif (in Ukrainian). Geologichnyi Zhurnal, 20: 17-26. 
Kuhnt, W., Kaminski, M., 1989. Upper Cretaceous deep-water agglutinated benthic foraminiferal assemblages from the western Mediterranean and adjacent areas. In: Cretaceous of the western Tethys. Proceedings $3^{\text {rd }}$ International Cretadceous Symposium, Tubingen 1987 (ed. J. Wiedmann): 91-120, Schweizerbart'sche Verlagsbuchhandlung, Stuttgart.

Kulchytskyi, Ya.O., Petrashkevych, M.I., Khloponin, K.L., 1957. On the stratigraphy of the Eocene of the Klippen Zone of the Eastern Carpathians (in Russian). Doklady AN SSSR, 115: 365-367.

Lomize, M.G., Maslakova, N.I., 1967. About the Upper Cretaceous age of the volcanic formations of the Gorinchevo-Polyansky area (Eastern Carpathians) (in Russian). Vestnik Moskovskogo Universiteta, 1: 115-118.

Luterbacher, H., Premoli Silva, I., 1964. Biostratigrafia del limite Cretacea-Terziario nell Appennino centrale. Rivista Italiana di Paleontologia e Stratigrafia, 70: 67-128.

Márton, E., Grabowski, J., Plašienka, D., Túnyi, I., Krobicki, M. Haas, J., Pethe, M., 2013. New paleomagnetic results from the Upper Cretaceous red marls of the Pieniny Klippen Belt, Western Carpathians: evidence for genral CCW rotation and implications for the origin of the structural arc formation. Tectonophysics, 592: 1-13.

Maslakova, N.I., 1955. Stratigraphy and Fauna of Small Foraminifera of the Paleogene Deposits of the Eastern Carpathians (in Russian). Gosgeolizdat. Moskwa.

Matskiv, B.V., 2009. State Geological Map of the Ukraine, scale 1:200,000. Carpathian series. Sheets M-34-XXXVI (Hust), L-35-I (Vişeu de Sus). Geological Map of the Pre-Quartery deposits (in Ukrainian). Published Ukrainian State Geological Exploration Institute, Kyiv.

Matskiv, B.V., Pukach, B.D., Hnylko, O.M., 2009. State Geological Map of the Ukraine, scale 1:200,000. Carpathian series. Sheets M-35-XXXI (Nadvirna), L-34-VI (Baia Mare). Geological Map of the Pre-Quarternary deposits (in Ukrainian). Ukrainian State Geological Exploration Institute, Kyiv.

Merten, S., Matenco, L., Foeken, J.P.T., Stuart, F.M., Andriessen, P.A.M., 2010. From nappe stacking to out-of-sequence postcollisional deformations: Cretaceous to Quaternary exhumation history of the SE Carpathians assessed by low-temperature thermochronology. Tectonics, 29: 1-28.

Mjatliuk, E.V., 1970. Foraminifers of the Flysch Deposits of the Eastern Carpathians (Cretaceous-Paleogene) (in Russian). Nedra, Leningrad.

Morkhoven, F.P.C.M., Berggren, W.A., Edwards, A.S., 1986. Cenozoic cosmopolitan deep-water benthic foraminifera. Bulletin des Centres de Recherches Exploration-Production Elf-Aquitaine, 11.

Morozova, V.G., 1946. About the age of the Lower Foraminiferal Beds of the North Caucasus (in Russian). Doklady Akademii Nauk SSSR, 54: 350-352.

Murray, J.W., 1976. A method of determining proximity of marginal seas to an ocean. Marine Geology, 22: 256-284.

Nagymarosy, A., Baldi-Beke, M., 1993. The Szolnok Unit and its probable paleogeographic position. Tectonophysics, 226: 457-470.

Olsson, R.K., Hemleben, Ch., Berggren, W.A., Huber, B.T., 1999 Atlas of Paleocene Planktonic Foraminifera. Smithsonian Contributions to Paleobiology, 85.

Olszewska, B., 1984. A paleoecological interpretation of the Cretaceous and Paleogene foraminifers of the Polish Outer Carpathians (in Polish with English summary). Biuletyn Instytutu Geologicznego, 346: 7-62.

Olszewska, B., 1997. Foraminiferal biostratigraphy of the Polish Outher Carpathians: a record of basin geohistory. Annales Societatis Geologorum Poloniae, 67: 325-337.

Olszewska, B., Odrzywolska-Bieńkowa, E., Giel, M.D., Pożaryska, K., Szczechura, K., 1996. Foraminiferida Eichwald, 1830. In: Geology of Poland. Atlas of characteristic fossils. Cenozoik. Tertiary. Paleogene. V. 3, part 3a (eds. L.
Malinowska and M. Piwocki): 45-215. Państwowy Instytut Geologiczny, Warszawa.

Oszczypko, N., 2006. Late Jurassic-Miocene evolution of the Outer Carpathian fold-and-thrust belt and its foredeep basin (Western Carpathians, Poland). Geological Quarterly, 50 (1): 169-194.

Oszczypko, N., Oszczypko-Cloves, M., Golonka, J., Krobicki, M., 2005. Position of the Marmarosh Flysch (Eastern Carpathians) and relation to the Magura Nappe (Western Carpathians). Acta Geologica Hungarica, 48: 259-282.

Pearson P.N., Olsson, K.R., Huber, B.T., Hemleben, Ch., Berggren, W.A., eds., 2006. Atlas of Eocene planktonic foraminifera. Cushman Foundation Special Publication, 41: $1-518$.

Săndulescu, M., 1988. Cenozoic tectonic history of the Carpathians. AAPG Memoir, 45: 17-26.

Săndulescu, M., 2009. The Black Flysch Nappe of the Maramureş East Carpathians - a "Valaisanne-Type" Tectonic Unit? Proceedings of the Romanian Academy, Series B, 1: 45-51.

Schmid, S., Bernoull, D., Fugenschuh, B., Matenco, L., Schefer, S., Schuster, R., Tischler, M., Ustaszewski, K., 2008. The Alpine-Carpathian-Dinaric orogenic system: correlation and evoIution of tectonic units. Swiss Journal of Geosciences, 101: 139-183.

Shutskaya, E.K., 1956. Stratigraphy of the lower horizons of the Paleogene in the Central Precaucasus according to the foraminifera (in Russian). Trudy Instituta Geologii AN SSSR, Geologicheskaya seria, 164: 3-114.

Ślączka, A., Kruglov, S., Golonka, J., Oszczypko, N., Popadyuk, I., 2006. Geology and hydrocarbon resources of the Outer Carpathians, Poland, Slovakia, and Ukraine: general geology. AAPG Memoir, 84: 221-258.

Smirnov, S.E., 1973. Paleogene of the Marmarosh and Pieniny Zones of the Ukrainian Carpathians (in Russian). Nedra, Moskva.

Smirnov, S.E., 1988a. The Drahovo Formation. In: The stratotypes of the Cretaceous and Paleogene deposits of the Ukrainian Carpathians (ed. S.I. Pasternak) (in Russian): 60-61. Naukova Dumka, Kiev.

Smirnov, S.E., 1988b. The Metova Formation. In: The stratotypes of the Cretaceous and Paleogene deposits of the Ukrainian Carpathians (ed. S.I. Pasternak) (in Russian): 109-113. Naukova Dumka, Kiev.

Smirnov, S.E., 1988c. The Shopurka Formation. In: The stratotypes of the Cretaceous and Paleogene deposits of the Ukrainian Carpathians (ed. S.I. Pasternak) (in Russian): 178-182. Naukova Dumka, Kiev.

Subbotina, N.N., 1953. Fossil Foraminifera of the USSR (Globigirinidae, Hantkeninidae and Globorotaliidae) (in Russian). Gosgeolizdat, Leningrad, Moskwa.

Subbotina, N.N., 1960. Pelagic foraminifera of the Paleogene of the southern USSR. In: Paleogene deposits of the south of the European part of the USSR (in Russian): 24-36. AN SSSR Press, Moskva.

Uchman, A., Malata, E., Olszewska, B., Oszczypko, N., 2006 Palaeobathymetry of the Outer Carpathian Basins (in Polish with English summary). In: Rozwój Paleotektoniczny Basenów Karpat Zewnętrznych i Penińskiego Pasa Skalkowego (eds. N. Oszczypko, A. Uchman and E. Malata): 85-102. Inst. Nauk. Geol. Uniwer. Jagiellońskiego, Kraków.

Ustaszewski, K., Schmid, S. M., Fügenschuh, B., Tischler, M., Kissling, E., Spakman, W., 2008. A map-view restoration of the Alpine-Carpathian-Dinaridic system for the Early Miocene. Swiss Journal of Geosciences, 101: 273-294.

Vialov, O.S., 1954. Mesozoic and Paleogene deposits of the flysch area (in Russian). The problem of industrial oil-bearing and gas-bearing of the western regions of USSR, 1: 48-74.

Vialov, O.S., 1988a. The Kalyna Formation. In: The stratotypes of the Cretaceous and Paleogene deposits of the Ukrainian Carpathians (ed. S.I. Pasternak) (in Russian): 67-70. Naukova Dumka, Kiev. 
Vialov, O.S., 1988b. The Sheshory Horizon. In: The stratotypes of the Cretaceous and Paleogene deposits of the Ukrainian Carpathians (ed. S.I.Pasternak) (in Russian): 173-176. Naukova Dumka, Kiev.

Vialov, O.S., Dabagyan, N.V., Myatlyuk O.V., 1963. About the age of the Globigerina Sheshory Horizon of the Carpathian flysch (in Ukrainian). Dopovidi Akademii Nauk URSR, 10: 1368-1372.

Vialov, O.S., Gavura, S.P., Danysh, V.V., Leshchuch, R.J., Ponomaryova, L.D., Romaniv, H.M., Tsarnenko, P.N., Tsizh, I.T., 1981. The History of the Geologic Development of the Ukrainian Carpathians (in Russian). Naukova Dumka, Kiev.

Vialov, O.S., Andreyeva-Grigorovich, A.S., Gavura, S.P., Dabagyan, N.V., Danysh, V.V., Kulchitskiy, Ya.O., Leshchukh, R. I., Lozynyak, P.Yu., Petrashkevich, M.Y., Ponomaryova, L.D., Romaniv, A.M., Tsarnenko, P.N., 1989. Explanatory report to the regional stratigraphic scheme of the Cretaceous deposits of the Ukrainian Carpathians (in Russian). Preprint of Institute of Geology and Geochemistry of Combustible Minerals, Lviv.

Wade, B.S., Pearson, P.N., Berggren, A.W., Pälike, H., 2011. Review and revision of Cenozoic tropical planktonic foraminiferal biostratigraphy and calibration to the geomagnetic polarity and astronomical time scale. Earth-Science Reviews, 104: 111-142.

Waśkowska, A., 2008. The Early Eocene Saccamminoides carpathicus Assemblage in the Outer Flysch Carpathians. Grzybowski Foundation Special Publication, 16: 331-341.

Waśkowska, A., 2015. The Eocene Hieroglyphic Beds of the Silesian Nappe in the Western Polish Carpathians - their development and foraminiferal record. Geological Quarterly, 59 (2): 271-299.

Waśkowska-Oliwa, A., 2005. Foraminiferal palaeodepth indicators from the lower Palaeogene deposits of the Subsilesian Unit (Polish Outer Carpathians). Studia Geologica Polonica, 124: 297-324.

Waśkowska-Oliwa, A., 2008. The Paleocene assemblages of agglutinated foraminifera from deep-water basinal sediments of the Carpathians (Subsilesian Unit, Poland): biostratigraphical remarks. Grzybowski Foundation Special Publication, 13: 227-265. 